\title{
Sokağa Çıkma Yasağına İlişkin Emirnameler: KKTC'de Salgın Hastalıkla Mücadelede Olağan Hukuk ile Olağanüstü Tedbirler
}

\author{
Demet Çelik Ulusoy* ${ }^{\oplus}$, Emine Uzuner* ${ }^{*}$
}

Öz

Tüm dünyada etkisini gösteren yeni tip korona virüs (Covid 19) salgın hastalığı, hükümetlerin etkin ve hızı kararlar almasını ve anayasal devletin sınıllarının sorgulanmasını gerektiren bir dönem olmuştur. İ̧̧inde bulunduğumuz dönemin, koşulları ve ortaya çıkardığı sonuçları itibariyle olağanüstü olduğuna şüphe yoktur. Hukukun üstünlüğüne dayanan demokratik bir devlette, ister olağan isterse olağanüstü dönemlerde olsun, iktidarın kullanılması bakımından siyasi iktidarlar her koşulda hukukla sınırlıdırlar. Olağanüstü durumlarla olağan hukuk çerçevesinde hareket etmek hukuk devletinin sınırlarıı zorlayabilir. Bu tür olağanüstü durumlarla mücadele etmek için olağan hukukun uygun araçları da sunması gerekir. Bu araçların bulunmadığı durumlarda ise olağanüstü hukukun uygulanması beklenir. Bu süreç içerisinde Kuzey Kıbrıs'ta da salgın hastalığın önlenmesi amacıyla hızı tedbirler alınarak uygulanmıştı. Çalışmada, olağanüstü durum ilanına gerek duyulmaksızın, temel hak ve hürriyetlerin durdurulması sonucunu ortaya çıkaran sokağa çıkma sınırlamasının hukuki boyutu üzerinde durulacaktır. Konu, Anayasa'nın temel ilkeleri üzerinden incelenecek, olağan hukuk kurallarıyla alınan salgın tedbirlerinin anayasallığı tartı̧ılacaktır.

Anahtar Kelimeler
KKTC Anayasası, Sokağa Çıkma Yasağı, Gezi ve Yerleşme Özgürlüğü, Emirnameler, KKTC'de Temel Hak ve Özgürlükler

Orders for Curfew: Extraordinary Measures with Ordinary Law in Struggle against Epidemic Disease

\begin{abstract}
A new type of coronavirus epidemic affects the entire world. It requires governments to make quick and impactful decisions that push the limits of the constitutional state. There is no doubt that this period is extraordinary due to the circumstances of the situation and the consequences it produced. However, political power is limited in a democratic state based on the rule of law, whether circumstances are ordinary or extraordinary. Legal boundaries get pushed in exceptional circumstances within the framework of existing rules. Ordinary law must offer appropriate tools to combat extraordinary times. In the absence of these tools, extraordinary law is usually enforced. In the process, the Turkish Republic of Northern Cyprus (TRNC) Government has started to implement rapid measures to prevent epidemics. This study focuses on the legal dimension of the curfew. It reveals the outcome of the cessation of fundamental rights and freedoms without the need for an emergency declaration. The curfew will be evaluated based on the constitutional principles and the constitutionality of epidemic measures taken under the usual law regulations.
\end{abstract}

\section{Keywords}

TRNC Constitution, Curfew, Freedom of Movement and Residence, Orders, Fundamental Freedom and Rights in TRNC

* Sorumlu Yazar: Demet Çelik Ulusoy (Yrd. Doç. Dr.), Doğu Akdeniz Üniversitsi, Hukuk Fakültesi, Anayasa Hukuku Anabilim Dalı, Gazimağusa, KKTC. E-posta: demet.celik@emu.edu.tr 0000-0002-5542-9467

* Emine Uzuner (Yüksek Lisans), Doğu Akdeniz Üniversitesi, Hukuk Fakültesi, Gazimağusa, KKTC. E-posta: emine.uzuner@emu.edu.tr ORCID: 0000-0002-7567-8858

Attf: Celik-Ulusoy D, Uzuner E, “Sokağa Çıkma Yasağına İlişkin Emirnameler: KKTC'de Salgın Hastalıkla Mücadelede Olağan Hukuk ile Olağanüstü Tedbirler" (2021) 79(2) İstanbul Hukuk Mecmuası 637. https://doi.org/10.26650/mecmua.2021.79.2.0008 


\section{Extended Summary}

Extraordinary circumstances such as epidemics, economic depression, or natural disasters can cause arbitrary government action in certain circumstances. In these circumstances, governments must make rapid and effective decisions to deal with extraordinary crises. Therefore, power restrictions can be halted temporarily and political powers rarely remain on the edge of the constitutional state borders. Emergency declarations and international conventions are suspended, especially in democratic countries, since extraordinary measures are not taken with existing laws in the battle against epidemics. Therefore, the announcement of an unusual situation is preferred because the political power is not competent enough to appeal to extraordinary measures with legal powers in democratic countries. It was debated whether to impose a curfew with the emergency declaration of coronavirus cases that first appeared in the Turkish Republic of Northern Cyprus (TRNC).

The President of the TRNC requested a state of emergency per the Constitution, but the current government stated it was not necessary on that date. There have been several discussions on emergency declarations in public, and they have caused tension between the President and the government. The Constitution states that the Council of Ministers (CM) needs to meet under the minister of the Republic to declare a state of emergency. After that, the deputy Prime Minister and the Foreign Minister said a curfew was out of the question. However, due to the increasing number of cases, more extreme measures were needed.

The government resorted to preventative measures limiting constitutional rights and freedoms. In this context, the curfew, which limits the freedoms of movement and residence, protected by the Constitution (Article 22), is the main subject of this study. The study focuses on the legal dimension of the curfew. It reveals the result of ceasing fundamental rights and freedoms without the need for an emergency declaration. In this context, according to the Curfew Law (1955, Chapter 156) by the CM's Order, partial curfew was declared with few exceptions on March 23 2020. A regulation that predicts a curfew is an Order. The basis of the Order is Chapter 156, an English-era law on the island. An Order is a decision, verdict, written order, or legal process stemming from the Anglo-Saxon legal system in TRNC, especially in administrative law and judicial body proceedings.

In our current extraordinary time, the legislature gives broad regulatory power to the executive. Epidemic disease is a legitimate cause for declaring a curfew that imposes restrictions on travel freedom in the TRNC Constitution. Most importantly, rights and freedoms are limited only by law. Considering these basic constitutional rules, the legality and judicial supervision of the Curfew Law and the procedures carried out accordingly and their compliance with the Constitution, especially the 
fundamental rights and freedoms, should be examined. The law does not reflect the current political power enacted and applied here by the English government on that date. This law should not be enforced under the Constitution since it is unconstitutional. In our opinion, it is unconstitutional because Transitional Article 4 of the Constitution states, "The legislation in force on the date of the coming into operation of this Constitution shall continue to be in force, in so far as such legislation is not contrary to or inconsistent with the provisions of this Constitution." Therefore, the law is not in line with the restraint regime of rights and freedoms (Article 11). Its limits must be clear, predictable, and transparent by law with legitimate reasons. The legislative branch has recently enacted the Law on Infectious Diseases. This law has been inadequate in the fight against the current epidemic in terms of limiting travel freedom. In the Curfew Law context, the Order, as an administrative regulatory action, its enforcement, and related decisions, should be discussed within a constitutional framework. 


\title{
Sokağa Çıkma Yasağına İlişkin Emirnameler: KKTC'de Salgın Hastalıkla Mücadelede Olağan Hukuk ile Olağanüstü Tedbirler
}

\begin{abstract}
Giriş
Salgın hastalık, ekonomik bunalım veya doğal afet gibi olağanüstü durumlarda siyasi iktidarlar hızlı ve etkin kararlar almalıdır. Bu gibi durumlarda idarenin keyfi hareket etmesi söz konusu olabilir, iktidarın sınırlandırılması geçici olarak durdurulabilir. Siyasi iktidarlar bu tür özel durumlarda anayasal devletin sinırları içerisinde nadiren kalabilmektedirler ${ }^{1}$. Salgın hastalık mücadelesinde de olağan hukuk ile olağanüstü tedbirler alınmayacağından, özellikle demokratik ülkelerde olağanüstü hâl ilanları yapılmış ve uluslararası sözleşmeler askıya alınmıştır. Demokratik ülkelerde olağanüstü hâl ilanının daha fazla tercih edilmesinin nedeni, siyasi iktidarın olağanüstü tedbirlere olağan hukuk yetkileriyle başvurabilecek kadar yetkili olmayışıdır². Kuzey Kıbrıs Türk Cumhuriyeti’nde (KKTC) ilk ortaya çıkan korona virüs vakaları nedeniyle, olağanüstü durum ilanıyla ${ }^{3}$ sokağa çıkma yasağı konulup konulmayacağı tartışılmıştır. 13.03.2020 tarihinde KKTC Cumhurbaşkanı, KKTC Anayasası (AY) 124. madde (md) çerçevesinde, Başbakan ve Bakanlar Kurulu'nu olağanüstü toplantıya çağırarak, olağanüstü durum ilanı için gerekli usulün başlatılmasına öncülük etmişti. Olağanüstü durum ilanı kararının alınması için, Bakanlar Kurulu'nun Cumhurbaşkanlığı başkanlığında toplanması gerekmektedir. Ancak toplantıda olağanüstü durum ilanı için uzlaşı sağlanamamış, Bakanlar Kurulu bu konuda "daha temkinli ilerlemeyi" tercih etmiştir. Kamuoyunda olağanüstü durum ilanı üzerinden ciddi tartışmalar yaşanmış, Cumhurbaşkanı ile hükümet arasında da gerginliğe sebep olmuştur.
\end{abstract}

MüteakibenKKTCBaşbakan YardımcısıveDışişleriBakanı sokağa çıkmayasağının söz konusu olmadığını dile getirmiştir ${ }^{4}$. Ancak artan vaka sayıları nedeniyle, salgın hastalığın yayılmasını önlemek amacıyla daha ciddi tedbirler alınmasının gerekliliği ortaya çıkmıştır. Bu çerçevede 1955 tarihli Sokağa Çıkma Yasağı Yasası'nın (Fasıl 156) 2. maddesine göre ç1karılacak Bakanlar Kurulu Emirnamesiyle, 23.03.2020 tarihinden bazı istisnalara bağlı olarak kısmi sokağa çıkma yasağı ilan edilmiştir ${ }^{5}$. Sokağa çıkma yasağını öngören düzenleme bir emirname olup dayanağı ise İngiliz

Cengiz Gül, İktidarın Sinırlandirlması ve Hukuk Devleti (1. Bas1, Adalet Yayınevi 2010) 239.

Christian Bjørnskov ve Stefan Voigt, The State of Emergency Virus, 'Verfassungsblog On Matters Constitutional' (2020) $<$ https://verfassungsblog.de/the-state-of-emergency-virus/> Erişim Tarihi 05 Nisan 2020.

1985 KKTC Anayasası (AY), Kabul Tarihi: 05.05.1985 RG 07.05.1985. 124. maddesi (md): "Tabii afet, tehlikeli salgın hastalıklar veya ağır ekonomik bunalım hallerinde, Cumhurbaşkanı başkanlığında toplanan Bakanlar Kurulu, yurdun bir veya birden fazla bölgesinde veya bütününde, süresi üç ayı geçmemek üzere, olağanüstü durum ilan edebilir."

4 KKTC Başbakanlık, 'Bakanlar Kurulu Kararları Açıklandı' (13 Mayıs 2020) <http://kktcbasbakanlik.org/ArtMID/3765/ ArticleID/124068/> Erişim Tarihi 13 Mayıs 2020.

5 Kısmi Sokağa Çıkma Emirnamesi, EK III AE202, EK IV BÖLÜM I, ET(K-I) 459-2020 KKTC Resmî Gazete (RG) 22.03.2020/Sayı 48, <https://basimevi.gov.ct.tr/> Erişim Tarihi 25 Mayıs 2020 357. İstisnalar için bakınız: 22.03.2020 tarihli ve 48 Sayılı RG 541. 
döneminden kalan kısaca Fasıl 156 olarak belirtilen yasadır'. Bakanlar Kurulu'nun sokağa çıkma yasağını dayandırdı̆̆ı bu Yasa'nın, sokağa çıkma yasağının yeri, zamanı, sınırları kısacası kapsamı ile istisnalarını belirleyen ve düzenleyici işlem niteliğindeki emirnamelerin hukuken tartışılması gerekmektedir. Ayrıca Yasa ile birlikte emirnamelerde öngörülen yaptırım ve buna bağlı olarak alınan kararların anayasallığ da tartışılmalıdır. İçinde bulunduğumuz olağanüstü durumlarda devletler ya olağanüstü durumun gereklerini karşılamak için yasayı feda eder ve gerekli tedbirleri, hukuka aykırı olsa dahi alırlar veya yasama organı yürütmeye geniş bir düzenleme yetkisi verir. Özellikle ikinci durumda idarenin yetkileri genişlemiş olur ancak hukuk devleti ilkesi ihlâl edilmemiştir?. Hukuk devleti idarenin, en temel anlamda devlet faaliyetlerinin belirli olmasını gerektirir. Bunun için hukukun açık, belirgin ve herkese eşit uygulanması gerekir. Hukuk devleti ile somutlaşan hukuki güvenlik, belirginlik, ölçülülük, düzenli ve istikrarlı idare, kazanılmış hak veya suç ve cezada yasallık gibi birçok ilke hukuk devletine güvenin ihtiyacı olan kurallardır. Burada incelediğimiz konu tam da bu ikilemin değerlendirmesi üzerinedir. Zira burada sokağa çıkma yasağına ilişkin mevzuat ile buna bağlı olarak gerçekleştirilen işlemlerin, hukuka uygunluğu ve yargısal denetimi incelenmeli, bunların temel hak ve özgürlükler başta olmak üzere KKTC Anayasası'na uygunluğu irdelenmelidir.

\section{KKTC Hukukunda Emirname Rejimi}

Emirname; karar, emir (order), yazılı emir anlamına gelen ve KKTC'de Anglosakson hukuk sisteminin etkisiyle, özellikle idare hukuku alanında ${ }^{9}$ ve kural olarak yargı organının hukuki işlemleri arasındadır. KKTC Anayasa Mahkemesi'nin (AYM) bir kararında emirname sözcüğünün İngiliz hukuk sisteminin bir kavramı olarak Türk hukuk sistemine yabancı olduğu belirtilmiştir ${ }^{10}$. AY'de geçen emirnamelerden ilki (md 151) ${ }^{11}$ yargısal nitelikli işlemler olup, münhasıran Yargıtay tarafından

\footnotetext{
Sokağa Çıkma Yasağı Yasası, Kanun Numarası: Fasıl 156, Kabul Tarihi: 2 Mayıs 1955, The Cyprus Gazette/ Suplement No 2/ No 3821 5.05.1955.

Ergun Özbudun, ‘İngiliz Hukukunda Hükümet Tasarrufları' (1961) 18(1) Ankara Üniversitesi Hukuk Fakültesi Dergisi 333, 335.

8 Fazıl Sağlam, Anayasa Hukuku Ders Notlarl, (1. Basım, Yakın Doğu Üniversitesi Yayınları 2013) 370 ff.

9 KKTC Yüksek İdare Mahkemesi (YIM), Karar Sayısı (KS) 81/2007, D 4/2009, 27.02. 2009. Emir veya yazılı emir bu çalışmada KKTC özelinde ve anayasa hukuku bağlamında incelenecektir. Ancak bu işlemlerin düzenleyici işlem niteliği idare hukuku açısından ayrıca başka bir çalışmayla ele alınıp incelenmelidir. Genel olarak bu tür adsıı işlemler arasında ifade edilen işlemlerin, "hiyerarşik üst" niteliği olan yetkililerce, hiyerarşi yetkilerine dayanılarak, yasaları yorumlamak ya da açıklamak üzere çıkarıldığı, ancak maddi açıdan, kural koyucu nitelikte olmaları durumunda ise "adsız düzenleyici işlem" olarak kabul edilecekleri belirtilir. Emirnameleri de kapsayacak biçimde adsız düzenleyici işlemlere ilişkin ayrıntılı bir çalışma için bkz. Yeliz Şanlı Atay, 'Türk İdare Hukukunda Adsız Düzenleyici İşlemler' (2011) (Yayımlanmamış Doktora Tezi T.C. Ankara Üniversitesi Sosyal Bilimler Enstitüsü Kamu Hukuku (İdare Hukuku) Anabilim Dalı, Tez Danışmanı: Prof. Dr. Metin Günday, Ankara) 23-28. <https://dspace.ankara.edu.tr/xmlui/bitstream/handle/20.500.12575/33957/ Sanli\%20Atay_Yeliz_tez.pdf? sequence=1> Erişim Tarihi 15.02.2021.

10 KKTC Anayasa Mahkemesi (AYM), KS 9/93 (D 5/95), 29.06.1995.

11 KKTC AY md 151(3)'e göre bu emirnameler; 'Yetkisiz tutuklamanın kaldırılması için emirname (Habeas Corpus), bir yetkinin kullanılmasını sağlamak için emirname (mandamus), herhangi bir mahkeme veya yargı niteliğinde yetki kullanan herhangi bir makamın yanlış bir kararının uygulanmasını önlemek için emirname (Prohibition), bir makamın herhangi bir yetkiye dayanılarak işgal edildiğinin soruşturulmasına ilişkin emirname (quo warranto) ve herhangi bir mahkeme veya yargı niteliğinde yetki kullanan herhangi bir makamın kararının iptali için emirname (certiorari)'dir.
} 
çıkarılmaktadır. Diğer emirnameler ise (md 158) ${ }^{12}$, Başsavcı tarafından Resmî Gazete'de yayımlanarak yürürlüğe girenlerdir. Bu kuralların dayanağı 'common law' hukuk sisteminin etkisinden kaynaklanır ${ }^{13}$. Yüksek İdare Mahkemesi (YİM), emirname çıkarma yetkisinin idarenin bir hukuksal işlem türü olarak yasalarda düzenlendiğini belirtmektedir. Farklı yasalarda geçen emirnameler, idarenin düzenleyici işlemi olarak veya birel idari işlemi olarak kabul edilmektedirler ${ }^{14}$.

KKTC Anayasası'nda yürütme organına emirname çıkarma konusunda özel ve ayrıca bir yetki verilmemiştir. Yürütme yetkisi ve görevini kullanan Cumhurbaşkanı ve Bakanlar Kurulu'nun şekli anlamda, Anayasa ve yasalara uygun olarak (KKTC AY md 5) yaptıkları işlemler yürütme işlemidirler. Bu işlemler belli bir hukuki sonuç doğurmaya yönelik irade açıklamalarıdır. Yürütmenin ayrıca genel, soyut, sürekli ve objektif nitelikte "düzenleyici işlemler"i de bulunur ${ }^{15}$. İdarenin, özel hukuktaki gerçek ve tüzel kişilerin irade açıklamalarına oranla daha üstün olan bu türden nitelikli irade açıklamaları, icra ve infaz edebilme yani tek yanlı yürütebilme gücünü haizdir. $\mathrm{Bu}$ işlemlerin hukuk düzeninde yürütülebilirlik özelliği bulunur ${ }^{16}$.

Yürütme organının düzenleyici işlemler yapabilmesine ilişkin yetkisi Anayasa' da belirtilmiştir. Madde 110 'da yürütmenin düzenleyici işlemler yapabileceği ${ }^{17}$ "yürürlükteki mevzuatın, Başbakan ve Bakanlar Kurulunun kendilerine verdiği diğer yetkileri” kullanıp, görevlerini yerine getirebilecekleri ifade edilmektedir. Anayasa'da belirtilen yürütmenin düzenleyici işlemleri; yasa gücünde kararname (YGK), tüzük, yönetmelik ve "diğer düzenleyici işlemler"dir. Her ne kadar sadece ilk üç düzenleyici işlem sayılmış olsa da uygulamada yürütmenin "tebliğ", "karar”, "ilan”, “duyuru” vb adsız düzenleyici işlemleri de bulunduğu kabul edilmektedir. Doktrinde de yürütmenin düzenleyici işlem yapma yetkisinin takdir yetkisi olduğu ve Anayasa' da belirtilmeyen düzenleyici işlemlerin de yapılabileceği belirtilmektedir ${ }^{18}$. KKTC AY'sinde de yürütmeye adsız düzenleyici işlemler yapabilmesi konusunda takdir yetkisi verildiği kabul edilmelidir (md 110/5). KKTC AYM'nin bir kararında yürütmenin düzenleyici işlemlerine karşı oyunda değinen Yüksek Mahkeme'nin

\footnotetext{
12 KKTC AY md 158(4) gereğince Başsavcı gerekli gördüğü hallerde Resmi Gazete'de yayımlayacağı bir emirname ile; '(b) ...davasız çözümlenmesine yasa ile olanak tanınan yol trafik suçlarını, kendi yönerisi ve sorumluluğu çerçevesinde mahkemelerde kovuşturmak üzere, uygun göreceği bir polis mensubunu" ve (c)' ...bakanlıkların veya diğer kamu kuruluşlarının taraf olduğu davalarda, ilgili bakanlık veya diğer kamu kuruluşlarında görevli ve avukatlık yapmak ehliyetine sahip bir hukukçuyu, bu davaları mahkemelerde yürütmekle' yetkilendirebilir.

13 Zaim Necatigil, Kuzey Kıbrıs Türk Cumhuriyeti’nde Anayasa ve Yönetim Hukukunun Esasları ( 2. Bası, Lefkoşa: Işık Kitabevi 2015), 18, 300.

14 KKTC YIM, KS 81/2007, D 4/2009, 27.02. 2009.

15 Kemal Gözler, Türk Anayasa Hukuku Dersleri (22. Bas1, Bursa: Ekin Yay,2018) 373. Bu hususta ayrıca Yönetimin İșlem ve Eylemleri bakımından hukuksal işlemlerin çeşitleri için bkz. Şeref Gözübüyük, Yönetim Hukuku (13. Bası, Ankara, Turhan Kitabevi 2000) 250 vd.

16 İlhan Özay, Günışığında Yönetim (1. Bası, İstanbul: Alfa Yay 1994) 12.

17 AY'nın 110. md'si 3/(b) bendi gereğince "Başbakan ve Bakanlar Kuruluna sunulmak üzere bakanlığını ilgilendiren kararname, tüzük ve yönetmelikleri hazırlamak..." ve (c) bendi gereğince "Kendi bakanlığını ilgilendiren herhangi bir yasa ve bu yasalara uygun olarak çıkarılan tüzük ve yönetmeliklerin uygulanabilmesi için yönerge, genelge ve benzeri metinleri yayınlamak...".

18 Gözler, Türk Anayasa Hukuku Dersleri (n 15) 360 ff.
} 
bir üyesi, hukuk kuralları arasında bir hiyerarşi olduğunu, Anayasa ve yasalardan sonra gelen düzenlemelerin tüzük veya yönetmelik olabileceğini belirtmiştir. Yargıca göre bu husus Anayasa'da açıkça belirtilmiş olup yürütme organınca emirname gibi "başka düzenlemeler yapılması veya yapılan düzenlemelere başka bir isim verilmesi doğru" değildir. Bunun nedeni ise AYM'nin bu işlemleri soyut norm denetimi yoluyla denetlememesidir. Bu koşullar altında adı emirname olan düzenlemeler soyut norm denetiminden kaçırılabilir ${ }^{19}$. Yürütmenin adsız düzenleyici işlemleri kural olarak "yönetmelik benzeri" şeklinde anılmakta, yönetmelikler de sadece yazılı olmak ve ilan edilmek koşulları dışında, özel bir şekil şartına bağlı olmaksızın kamu hukukunun serbestçe yapabildiği işlemlerdir ${ }^{20}$.

Yürütme organının düzenleyici işlemleri yasaya dayanmalı (secundum legem), yasama organı gibi ilk elden bir düzenleme yapmamalıdır ${ }^{21}$. Yürütme organının düzenleme yetkisinin kaynağı yasadır. Dolayısıyla yürütme yetkisi, kendisine yasayla verilen yetki çerçevesinde kullanılabilir. Bu yetki aynı zamanda yasaya aykırı (intra legem) olmamalıdı2 ${ }^{22}$. Anayasa'nın 5. maddesi de yürütme yetkisinin Anayasaya ve yasalara uygun olarak kullanılması gerektiğini belirterek, yürütme organı düzenleyici işlemlerin yasanın çizdiği sınırlar içerisinde olması gerektiğini ortaya koymuştur.

KKTC'de salgın hastalıkla mücadelede başvurulan tedbirlerden biri olan ve sokağa çıkma yasağını düzenleyen 202 sayılı Emirname de yürütme organının düzenleyici işlemidir. İşlem şekli anlamda yürütme işlemi ancak maddi anlamda ise genel, soyut, objektif ve sürekli nitelikte olduğundan yasama işlemidir. Maddi kriter genel, soyut, objektif kişilik dışı ve sürekli nitelikteki işlemlerin sadece yasama işlemi niteliğinde olabileceğini belirtmektedir. Hâlbuki yürütmenin düzenleyici işlemleri de kural-işlem niteliğinde, genel, soyut objektiftir. Maddi nitelikleri açısından yasama işleminden ayrilmazlar. $\mathrm{Bu}$ nedenle maddi kriter idari fonksiyonu yasama fonksiyonundan ayırmaya imkan vermez ${ }^{23}$. Emirname yürütme organı tarafından yapılmakta, kaynağını yasalardan almaktadır. Anayasa Mahkemesi kararları ışığında, "Bakanlar Kurulu kararlarına istinaden yapıldığ için bir nevi Bakanlar Kurulu kararı sayılırlar". AYM emirnamelerin denetiminde ihtiyatlı davranmaktadır ancak bazı kararlarında verilen karşı oylarda emirnamelerin yönetmelik veya tüzük biçiminde düzenleyici işlem olmaları halinde iptal davasına konu olmaları gerektiği belirtilmiştir ${ }^{24}$.

Bakanlar Kurulu'nun sokağa çıkma yasağının dayanağı olan bu Emirnameler, İngiliz döneminden kalan 1955 tarihli Fasıl 156'ya dayanmaktadır. Bu Yasadan hareketle kabul edilen 202 sayılı Emirname ile gezi ve yerleşme özgürlüğüne sınırlama getirilmesi dışında, sokağa çıkma yasağına uymayanlar hakkında da

\footnotetext{
KKTC AYM, KS 9/93 (D 5/95), s. 173 29.06.1995.

Özay (n 16) 375.

Gözler, Türk Anayasa Hukuku Dersleri (n 15) 360.

Kemal Gözler, Anayasa Hukukunun Genel Esasları (10. Bası, Bursa: Ekin Yay 2018) 374.

23 Gözler, Anayasa Hukukunun Genel Esasları (n 22) 373. Ayrıca bkz. Kemal Gözler, Anayasa Hukukunun Genel Teorisi: Cilt 1 (2. Bas1, Bursa: Ekin Yay 2020) 893-894.

24 KKTC AYM, KS 9/93 (D 5/95), 29.06.1995.
} 
yürürlükteki mevzuat çerçevesinde yaptırım uygulanacağı ifade edilmiştir. Bakanlar Kurulu bu yaptırımı düzenleyen Fasıl 156'nın suç ve cezalara ilişkin son hükmünü (md 4) değiştirerek güncellenmiştir. Ancak bu değişiklik, 8/2020 sayılı Yasa Gücünde Kararname ile kabul etmiştir ${ }^{25}$. Bu çerçevede öncelikle bütün bu işlemlerin temeli olan Fasıl 156'nın anayasaya uygunluğu tartışılmalıdır.

\title{
II. Sokağa Çıkma Yasağının Anayasaya Uygunluğunun İncelenmesi
}

Salgın hastalık mücadelesinde özellikle en temel başvurulan tedbir gezi ve yerleşme özgürlüğünü sınırlayan ve sokağa çıkma yasağı öngörerek bunu yaptırıma bağlayan sokağa çıkma yasaklarıdır. Bu çerçevede öncelikle Sokağa Çıkma Yasağı Yasası, Bakanlar Kurulu'nun Sokağa Çıkma Yasağı koymasına ilişkin yetkisi ve bu çerçevede yürürlüğe konulan emirnamelerin anayasal denetimi incelenmelidir.

\section{A. Sokağa Çıkma Yasağı Yasası'nın Anayasaya Uygunluğu}

\section{Kanunlar doğru oldukları için değil yasa oldukları için yürürlükte kalırlar.}

\author{
Michel de MONTAIGNE ${ }^{26}$
}

Yürütme organı sokağa çıkma sınırlamalarına ilişkin yetkisini, Fasıl 156’ya (md 2) dayandırmıştır. Buna göre;

"Bakanlar Kurulu, kamu güvenliği ve kamu düzeninin idamesi için emretmeyi uygun görmesi halinde, herhangi bir zaman bir Emirname ile hiçbir kişinin, Emirnamede belirlenecek bir kişinin vereceği yazılı bir iznin verdiği yetki olmadan Emirnamede belirlenecek alan içinde ve saatler arasında sokağa çıkmamasını emredebilir"'27.

İlgili madde, hukuk dili açısından anlaşılır nitelikte olmadığı gibi, yürütme organına sınırları çizilmemiş, belirsiz ve geniş bir takdir yetkisi vermiştir. Bugüne değin 202 Sayılı Emirname başta olmak üzere diğer birçok emirnameyle sokağa çıkma yasakları öngörülmüş, salgın hastalıkla ilgili gelişmelere göre bu emirnamelerde değişiklikler yapılmıştır ${ }^{28}$.

\footnotetext{
İlgili 8/2020 Sayılı Yasa Gücünde Kararname, 50 Sayılı RG İle 25.03.2020'de yayımlanarak yürürlüğe konulmuştur. Sokağa Çıkma Yasağı Yasası Hakkında Yasa Gücünde Kararname, Kabul Tarihi: 23.03.2020 Kararname Sayı: 8/2020 E.T(K-I) 4882020 RG 25 Mart 2020/50/s 127.

26 Özay (n 16) 695.

27 Fasıl 156 Sokağa Çıkma Yasağı Yasası'nın ilgili 2. md devamında ‘Ancak Bakanlar Kurulu, Emirnamede belirlenecek kişileri veya belirli sınıflardaki kişileri Emirname kurallarından bağışık tutabilir. Yine ancak, Bakanlar Kurulu, Emirnamede belirlenecek herhangi bir kişiye, mutlak takdirine göre, Emirnamedeki herhangi bir belirli alanda (veya herhangi bir kısmında) Emirnamenin uygulanmasını askıya almaya, askıya almayı sona erdirmeye ve Emirnamenin yürürlükte olduğunu ilân etmeye yetki verebilir' ibaresi yer almaktadır.

28 KKTC Bakanlar Kurulu 22.03.2020 tarihinde 48 Sayılı RG İle ilk olarak 202 Sayılı Kısmı Sokağa Çıkma Yasağı Emirnamesi kabul ederek yayınlamıştır. Bugüne değin aynı konuda birçok emirname yayınlanmıştır. Ancak ilk emirnamenin ardından Bakanlar Kurulu, 25.03.2020 tarihinde 50 Sayılı RG'de 8/2020 sayılı Sokağa Çıkma Yasağı Yasası Hakkında Yasa Gücünde Kararname yayınlayarak 202 Sayılı Emirnameye uymayanlar aleyhinde yaptırım öngörmüş ve Fasıl 156'nın 4. maddesinde öngörülen suç ve cezalara ilişkin hükmünü bu kararname ile değiştirmiştir. BK bunun dışında sırasıyla; 51, 54, 57, 58, 59, 62, 68, 71, 73, 76 ve 79 sayılı Resmî Gazetelerde sokağa çıkma yasaklarına ilişkin emirnameler yayınlamıştır. <http:// basimevi.gov.ct.tr/.>
} 
Emirnamelerin dayandığı ilgili Fasıl 156 Kıbrıs'ın İngiliz döneminde çıkarılmış bir yasadır ${ }^{29} .1955$ tarihli Yasa, bugün ne Güney Kıbrıs'ta ne de İngiltere'de uygulanmamaktadır ${ }^{30}$. Yasa'nın KKTC'de halen yürürlükte olması, Jefferson'ın yeni kuşaklar teorisini akla getirmektedir. $\mathrm{Bu}$ teoriye göre geçmiş kuşakların iradeleri gelecek kuşakları bağlamaz. Her anayasa ve her yasa doğal olarak 19 yılın sonunda yürürlükten kalkmalıdır. Böylelikle bir sonraki kuşağın yürürlükten kaldırma yetkisini kullandığı söylenebilir, bu da onları özgür kılacaktır ${ }^{31}$. Jefferson "Dünya yaşayanlara aittir, ölülere değil"’32 sözüyle, her kuşağın hangi siyasal, hukuki ve ekonomik kurumlar içinde yaşamak istediğine karar verme konusunda özgür olduğuna işaret etmiştir ${ }^{33}$. Dolayısıyla Fasıl 156'nın yürürlükte olması bugün salgın hastalık nedeniyle uygulanmış olması bugünün kuşaklarının belirli bir ihtiyacından kaynaklanmamaktadır. Yasa'nın hala yürürlükte olması hem siyasi iktidarların bu tür boşlukları doldurma konusundaki zayıflı̆̆ını göstermekte hem de çok yakın zamanda KKTC'de yürürlüğe giren 45/2018 sayılı Bulaşıcı Hastalıklar Yasası'nın yeterince nitelikli olmadığını göstermektedir. Zira içinde bulunduğumuz salgın hastalık ile mücadelede öncelikle uygulama alanı bulması gereken norm Bulaşıcı Hastalıklar Yasasıdır. Ayrıca, Anayasa'da açıkça güvence altına alınan gezi ve yerleşme özgürlüğüne getirilecek sinırlamalar da bu koşullarda yine bu 45/2018 sayılı Yasada öngörülmüş olmalıydı.

Şüphesiz Fasıl 156'nın hala yürürlükte olmasının kaynağını Anayasa'da aramak gerekir. Öncelikle 1960 Kıbrıs Cumhuriyeti (KC), daha sonra 1975 Kıbrıs Türk Federe Devleti (KTFD) ve son olarak 1985 KKTC Anayasalarında bu tür eski dönemlerden kalan yasaların yürürlügü için geçici maddeler öngörülmüştür. Fasıl 156 KKTC Anayasası gereğince yürürlükteki mevzuat sayıldığına göre, 1975 KTFD ve hatta 1960 KC döneminde de yürürlükte olduğu söylenebilir. Nitekim KC AY'sine göre (md 188) cumhuriyetin kurulduğu süreçte yürürlükte olan yasalarla ilgili olarak şu hüküm bulunmaktadır;

29 İngiliz idaresi altında 1957 yılında bu Yasaya bağlı olarak Karavas, Larnaca ve Lapithou bölgelerinde sokağa çıkma yasakları getirilmiştir. The Cyprus Gazette, Supplement No. 3, Subsidiary Legislation (28.11.1957) <https://sbaadministration. org/home/legislation/01_02_09_02_PartII-SubLeg-Cyprus/CyGaz-.pdf> Erişim Tarihi 10 Nisan 2020. Yasa'nın o tarihte uygulanması Yunanistan ve İ́ngiltere arasında Avrupa İnsan Hakları Sözleşmesi'nin ihlal edildiği gerekçesiyle davaya konu olmuştur. Greece v. United Kingdom kararı AİHS 15. maddeye ilişkin ilk dava olarak ifade edilir. Bu Karar'da İngiliz Hükümetinin Kıbrıs'ta o dönemde olağanüstü hal ilan etmesi özellikle Yunan Devleti tarafından tartışmalara konu olmuştur. Komisyon İngiltere İmparatorluğunun bir parçası olarak Kıbrıs’ta böyle bir ilanın yapılmasının hükümetin ilgili takdir yetkisini belirli sınırlar içinde muhafaza edeceğini belirtmiştir. Karara göre Hükümet milletin hayatının tehdit edildiği durumlarda bir takdir yetkisi sahiptir ancak bu takdir yetkisi Avrupa denetimine tabi olacaktır. Greece v. United Kingdom, Appl. No. 176/56, (26.09.1958) Ayrica bkz Bart van der Sloot, 'Is All Fair in Love and War? An Analysis of the Case Law on Article 15 ECHR' (2014) 53 (1) Military Law and the Law of War Review <https://bartvandersloot.com/onewebmedia/ Is_all_fair_in_love_and_war_forthcomming.pdf $>26.04 .2020$.

30 Adada Kıbrıslı Türklerin idaresinde sırasıyla; 1878-1960 yılları arasında "İngiliz” idaresi; 1960 "Kıbrıs Cumhuriyeti; 19631967 arasında Türk toplumu “Genel Komite”; 1967'de "Kıbrıs Geçici Türk Yönetimini”; 1974 sonrası "Otonom Kıbrıs Türk Yönetimi”; 1975 'te “Kıbrıs Türk Federe Devleti”ve 1983 tarihinde "Kuzey Kıbrıs Türk Cumhuriyeti” ilanı edilmiştir. KKTC Anayasası 07.05.1985’te yürürlüğe girmiş bugüne değin uygulanmaktadır. Necatigil (n 13) $1 \mathrm{ff}$.

31 Thomas Jefferson, 'Thomas Jefferson to James Madison' (1789) 15(27) Princeton University Press 1958, $392<$ https:// jeffersonpapers.princeton.edu/selected-documents/thomas-jefferson-james-madison> Erişim Tarihi 20 Mart 2020.

32 David A Strauss, 'Common Law, Common Gorund and Jefferson's Principle' (2003) 112 The Yale Law Journal $1717,1721$.

33 Salih Akkanat, 'Kurucu İktidara Dayalı Bir Demokrasinin İmkânı: Siyasal Bir Yaklaşımı' (2015) 48(2) Amme İdaresi Dergisi 1, 6 . 
“...Anayasanın yürürlüğe girdiği tarihte yürürlükte bulunan bütün yasalar, ...gerek değiştirme, gerek ilave veya gerekse kaldırma sureti ile, tadil edilinceye kadar; bahis konusu tarihte ve bundan sonra yürürlükte kalırlar ve bahis konusu tarihten itibaren bu Anayasaya uymaları için yapılması gerekli tahvillerin yapılması suretile yorumlanır ve uygulanır"’34.

Fasıl 156 sayılı Yasa'nın orijinal metninde, sokağa çıkma sınırlaması konması konusundaki yetki, o dönemin İngiliz hükümetince atanan Vali'ye verilmiştir. Vali, "kamu güvenliği” ve "kamu yararı" doğrultusunda gerek görürse, herhangi bir yerde sokağa çıkma yasağı ilan edebilir. Vali’nin bu yetkisini bir karar biçiminde kullanacağı belirtilmiştir ${ }^{35}$. Yasa'nın İngiliz döneminde Vali’ye verdiği sokağa çıkma yasağına ilişkin Karar yetkisinin, bugünkü şekliyle Bakanlar Kurulu’na emirname çıkarması biçiminde değiştirildiği görülmektedir. Yasa'nın nasıl güncel hukuk düzenine uyarlanacağı konusundan $\mathrm{KC}$ AY'sinde ayrıntılı düzenleme yapılmıştır. Anayasa'nın md 188/3 (b) bendinde İngiliz dönemindeki yasalarda Valiye veya Valilik Meclisi'ne yapılan atıflar;

"bu Anayasanın açık hükümlerine göre, ayrı ayrı veya müştereken Cumhur Başkanına ve Cumhur Başkan Muavinine, Cemaat Meclislerine açıkça ayrılanlar dışında teşrîi kuvvetin kullanılması ile ilgili konularda Temsilciler Meclisine, bu Anayasa gereğince yetkisine dâhil bütün konularda ilgili Cemaat Meclisine ve icra kuvvetinin kullanılmasına dair konularda Bakanlar Kuruluna" yapılan atıflar olarak kabul edilecektir.

Ayrıca AY’nin “...herhangi bir hükmüne aykırı veya uyuşmaz olan” (md 188/2) hiç bir yasa yürürlükte kalamayacaktır. KC AY'sinin ardından gelen 1975 KTFD AY'sine göre, o tarihe kadar kabul edilmiş mevzuatın “anayasanın kurallarına veya bu anayasa uyarınca uyulacak kurallara aykırı olmayanları, yürürlükte"dir ${ }^{36}$. KKTC'de Fasıl 156'nın yürürlükte olmasının dayanağı ise, KKTC AY'nin Geçici 4. maddesidir. Maddeye göre “...Anayasanın yürürlüğe girdiği tarihte yürürlükte olan mevzuat, bu Anayasa kurallarına aykırı olmadığı ölçüde yürürlükte” kalacaktır.

Yukarıda verilen geçici hükümler arasında en detaylısı 1960 KC Anayasasında bulunmaktadır. AY'de (md 188/4) “....yürürlükte kalan herhangi bir yasanın hükümlerini uygulayan Cumhuriyet dahilindeki herhangi bir mahkeme, .... bu Anayasa hükümlerine uygun kılmak için gerekli olabilecek tahvilleri yaparak uygular" denilmektedir. Buna göre İngiliz döneminde kabul edilmiş yasalarda, geçen her ifadenin otomatik olarak belirli bir organa tevdi edilmeyeceği, işlemin niteliğine

${ }^{34}$ Kıbrıs Cumhuriyeti Anayasası madde 188, 1960 Kıbrıs Cumhuriyeti Anayasası, Numarası:0/1960, Kabul Tarihi:06.04.1960 Yürürlük Tarihi:16 Ağustos 1960.

35 Curfew Law, 1955 Cyprus Law, <http://www.cylaw.org/nomoi/arith/1955_1_017.pdf> Erişim Tarihi 02 Nisan 2020; Yasa'nın ilgili orijinal metni şu şekildedir; "The Governor may, if he deems it expedient so of to do in the interests of public safety and the, Curfews maintenance of public order, at any time by Order direct that no person in any area specified in the Order shall be out of doors between such hours as may be prescribed by the Order except under the authority of a written permit granted by such person as may be specified in the Order:" Yasanın tam orijinal adı "A Law to Provide for The Imposition of Curfews in the Interests of Public Safety and the maintenance of Public Order" biçimindedir. Supplement No. 2, Legislation The Statute Laws of Cyprus No. 11 of 1955 The Cyprus Gazette No. 3821, Kabul Tarihi: 05.05.1955.

36 Kıbrıs Türk Federe Devleti Anayasası (KTFD), Numarası: 0/1975, Kabul Tarihi: 13 Şubat 1975 Yürürlük Tarihi: 08.06.1975 Geçici md 1. 
göre yorumlanacağı belirtilmiştir. Özellikle yasama yetkisinin kullanılmasına ilişkin konularda bu yetkinin yasama organının yetkisi biçiminde yorumlanması gerektiği belirtilmiştir.

Somut olayda da Fasıl 156 gibi kapsamı ve içeriği ile sınırlı olan bir Yasa'ya dayanılarak, yürütmeye temel hak ve özgürlükleri sınırlayıcı nitelikte idari bir işlem olan Emirname ile sokağa çıkma yasağının getirilmesi yetkisi verilmektedir. Bu açıdan bakıldığından ilk etapta Anayasa'ya yasallık, hukukun üstünlüğü, hukuki güvenlik ve belirlilik açısından aykırıdır. KKTC AYM iç hukuk düzenlemeleri bakımından devletlerin hukuki kesinlik veya yasallık ilkelerine uyum göstermesinin Avrupa İnsan Hakları Mahkemesi (AİHM) kararları bakımından gerekli olduğu, bu gerekliliği yerine getirilmediği durumlarda sınırlama tedbirleri açısından devletin amaçlarının meşruiyetini veya orantılığını ele almak için de bir sebep kalmayacağı aktarılmıştır ${ }^{37}$.

Avrupa İnsan Hakları Sözleşmesi (AİHS) KKTC Hukuku bakımından da iç hukukta ve yasalarla eş değer kabul edilmektedir ${ }^{38}$. AIHHM'in yerleşik içtihatlarına göre temel hak ve özgürlüklere getirilecek sınırlamaların yasa ile öngörülmesi, sadece iç hukukta bir dayanağının olmasını değil, aynı zamanda onun 'yasa niteliğine' de sahip olmasını gerektirir. Mahkeme maddi anlamda yasa anlayışını benimsemekte ve somut olayda sınırlama aracının adı ile bağlı olmayıp, yasa niteliğini taşıyıp taşımadığını araştırmaktadır ${ }^{39}$. Mahkeme sınırlama aracı olarak yasanın kaliteli olmasını, sınırlamada başvurulan tedbirin aynı zamanda "yasa kavramının niteliklerini taşıması" gerektiğini belirtir. Kısaca bir düzenlemenin adının yasa olması yeterli değildir aynı zamanda nitelikli, kaliteli olması da gerekir. Buna göre yasa aynı zamanda ulaşılabilir, "erişilebilir" olmalı, "kişilerin belirli bir eylemin doğurabileceği sonuçları, şartların izin verdiği ölçüde öngörebilmelerini ve davranışlarını düzenlemelerini, gerekirse uygun tavsiyeler ile birlikte sağlayacak şekilde yeterli kesinlikte formüle " edilmiş olmalıdır. Her ne kadar AİHM içtihatlarında bir düzenlemenin yasa biçiminde nitelendirilmesi, Sözleşmeye uygun bir sınırlama yapıldığı anlamına gelmez. Bunun yanında yasa ulaşılabilir olmalı ve bireylerin davranışlarını kurallara göre ayarlayabileceği ölçüde açık ve sarih, öngörülebilir olmalıdır ${ }^{40}$. Mahkeme bu tür bir yasanın "öngörülebilir", "belirli olması" kriterlerini de "hukuki güvenlik" açısından aramaktadır ${ }^{41}$.

\footnotetext{
KKTC AYM, KS 14/2015, D 9/2017, 29.06.2017, 26.

38 KKTC AY md 90.39/1962 sayılı İnsan Haklarını ve Ana Hürriyetleri Korumaya Dair Avrupa Sözleşmesi Ve Buna Ek Protokolün Tasdiki Hakkında Yasa Kanun Numarası: 39/1962, Kabul Tarihi:24.05.1962, Cyprus Government Gazette No 157, Supplement I.

39 Kerem Altıparmak ve Onur Karahanoğulları, 'Pyrrhus Zaferi: Leyla Şahin/Türkiye, AİHM/Hukuk, Düzenleyici İşlem/ Kanun' (2004) 3 (1) Hukuk ve Adalet Dergisi 249, 254 ff.

40 Gülcü v Türkiye App no 17526/10 (ECHR, 2016 ) ; Sunday Times v Birleşik Krallık, (no 1) Series A no 30 App No:6538/74 (ECHR,26 Nisan 1979) para 49.

${ }_{41}$ Association Ekin v Fransa App no 39288/98 (ECHR,2001) <https://hudoc.echr.coe.int/eng\#\{itemid:[001-59603]\}> Erişim Tarihi 19 Nisan2020.
} 
Mahkeme "yasa" kavramını oldukça geniş yorumlamaktadır. Ona göre yasa kısaca yetkili mahkemelerin yorumladığı şekliyle yürürlükte olan hükümdür ${ }^{42}$. Common law hukuk düzeninde, yazılı olmayan hukuk da yasayla düzenleme kavramı içerisinde değerlendirilmektedir. AİHM, idarenin düzenleyici işlemleri ve yargıç yapımı hukukun da yasallık ilkesini karşıladığını kabul etmektedir ${ }^{43}$. Yasayla öngörülme kriteri yukarıda belirtilen; ilgili kişiler açısından yeterli derecede ulaşılabilir olması ve hükmün ilgili kişilerin, davranışlarını bu hükme göre yönlendirebilme ve eylemlerinin sonuçlarını belli koşullar altında öngörebilmeye olanak sağlayacak kadar açık olması ilkeleri dışında, müdahalenin mevzuatta ya da yargı içtihatlarında yer alan bir hükme dayanması ilkesini de içerir ${ }^{44}$. Sokağa çıkma yasaklarına ilişkin emirnameler maddi niteliği itibariyle bir yasa işlemi olarak kabul edilse dahi, Fasıl 156 da dâhil olmak üzere, AİHM' in kaliteli yasadan beklediği kriterleri karşılamamaktadır. TC Anayasa Mahkemesi sınırlamalar bakımından hem şekli anlamda yasa kriterini, hem de içerik olarak belirli bir amacı gerçekleştirmeye elverişli olmasının gerekliliğini ortaya koymaktadir ${ }^{45}$.

KKTC konum itibariyle birçok medeniyetin ve dolayısıyla birçok hukuk sisteminin etkisi altında kalmış, ancak kendi iç hukukunu yenileme konusunda yeterince etken olamamıştır. KKTC'ye oranla vaka sayısı daha fazla olan Güney Kıbrıs'ta da sokağa çıkma yasağı da dâhil olmak üzere birçok tedbir alınmaktadır. Orada alınan tedbirlerin 1932 tarihli ve Fasıl 260 sayılı Karantina Yasası'na (Fasıl 260) dayandırıldı̆̆ı görülmektedir ${ }^{46}$. Fasıl 260 KKTC'de de yürürlükteydi ve içeriğinde kısaca kamu sağlığı nedeniyle alınacak tedbirler öngörülmekte, salgın hastalık nedeniyle Bakanlar Kurulu'nun alacağı tedbirlerin çerçevesini, bu tedbirlerin hangi amaçla nasıl alınacağı, tedbirlere uyulmaması halinde uygulanacak yaptırımları biraz daha kapsamlı düzenlemekteydi. Daha detaylı nitelikteki bu Yasa, 2018 tarihli Bulaşıcı Hastalıklar Yasasıyla yürürlükten kaldırılmıştır ${ }^{47}$. Ancak ne ilginçtir ki 2018 yılında yürürlüğe giren bu Yasa salgın hastalık kapsamında alınan tedbirleri karşılayamamış, KKTC hükümeti salgın hastalıkla ilgili aldığı sınırlayıcı tedbirleri daha eski tarihli ve kapsamı dar olan 4 maddelik Fasıl 156 kapsamında almıştır. Tam olarak salgın hastalıklarla ile ilgili olsa da ne yazık ki Bulaşıcı Hastalıklar Yasası konuya ilişkin hükümlerde yeterince net değildir.

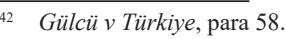

43 Altıparmak ve Karahanoğulları (n 39) 255.

44 Haşim Özpolat, ‘Anayasa Mahkemesi’nin Bireysel Başvuru Kararlarında Maddi Anlamda Kanun Kriteri’ (2018) 9(33) TAAD 609, 610 .

45 Ali Karatay Başvurusu, AYM 2012/990, 10.12 .2014 para 48; Özpolat (n 44) 610 ff.

46 Güney Kıbrıs bu süreçte Karantina Yasası'ndan aldığı yetkiyle kararnameler ile düzenleme yapmaktadır. Bkz Minister of Health, 'Minister of Health to issue new decree under the Quarantine Law Act', (Minister of Health Cyprus, 30.03.2020) $<$ https://www.pio.gov.cy/coronavirus/en/press/30032020_19.pdf > Erişim Tarihi 18 Nisan 2020. Karantina Yasası, The Quarantine Law, 1932, Kabul Tarihi: 26.02.1932. RG 09.03.19327 Cyprus Gazette No. 2201 of the No. 17 of $1932<$ http:// www.cylaw.org/nomoi/arith/1932_1_017.pdf> Erişim Tarihi 03 Nisan 2020

47 45/2018 Sayılı Bulaşıcı Hastalıklar Yasası, Kanun Numarası: 45/2018, Kabul Tarihi: 10 Aralık 2018. <https://www. mahkemeler.net/birlestirilmis/45-2018.docx> Erişim Tarihi 17 Mart 2020. 
Yasa çă̆ın gereklilikleri ve salgın hastalıklar konusunda oldukça detaylı düzenlemeler içermesine rağmen, salgın hastalık nedeniyle sokağa çıkma sınırlaması öngörmemiştir. Yasa böyle bir sınırlama getirmiş olsayd1, gezi özgürlüğüne uygun nitelikte olabilecekti. Zira AY'de gezi özgürlüğü, ancak ulusal güvenliği sağlama ve salgın hastalıkları önleme amaçlarıyla ve yasayla sınırlanabileceği öngörülmüştür (md 22). 45/2018 sayılı bu Yasa'da KKTC'de 'tehlikeli bir epidemik veya bulaşıcı hastalığın tehdidi veya etkisi altında olduğunda, Bakanlık, bir hastalığın önlenmesi ve hafifletilmesi için Dünya Sağlık Örgütünün önerilerini dikkate alarak uygun bulduğu hususlarda tedbirler" (md 36) alınabileceği belirtilmiştir. Burada da Fasıl 156'da olduğu gibi yürütmeye geniş, çerçevesi ve sınırları belirtilmemiş bir yetki verilmiş, tedbirlerin sınırları açık, öngörülebilir bir çerçevede ortaya konulmamıştır. 2018 tarihli bu Yasa' da değişiklik yapılmalı, salgın hastalıkların engellenmesi adına sokağa çıkma yasağı konulabilmesi için hükümetin yetkilerini açıkça ortaya koymalıdır. Bu yetkilerin sınırları da açıkça belirtilmelidir. Kanımızca ancak bu şekilde AY'deki gezi ve yerleşme özgürlüğ̈̈ne uygun bir yasal düzenlemeden söz edilebilir.

Mevcut sokağa çıkma yasağının dayanağı olan Fasıl 156 önemli ölçüde meşruiyetini kaybetmiş bir yasadır. Meşruiyet sadece yasallık kavramına indirgenemez. Kavram, "bir kurum veya kuralın kendinin üstünde bulunan hukuksal ya da etik bir norma uygun olmasını" ifade eder ${ }^{48}$. Dolayısıyla bir defalı̆̆ına tanımlanan ve her dönem geçerliliği bulunan bir olgu değildir, sürekli yenilenir ${ }^{49}$. Atay'a göre "zaman içerisinde gelişen ve değişen şartların sonucu olarak toplumda egemen olan meşruluk anlayışı değişebilir" sonuçta da pozitif normların toplumsal dayanakları ve etkinlikleri zayıflar. Dolayısıyla meşruiyet kaybedilir, siyasi iktidarın yasallık temeli ortadan kalkar ${ }^{50}$. Fasıl 156, yürürlüğe girdiği dönemin ruhunu yansıtan, o dönemin siyasi iktidarınca yürürlüğe konulmuş ve o dönem itibariyle uygulanmış bir Yasadır. O dönemin siyasi iktidarının olan kaynăğ İngiltere'de dahi uygulanmamaktadır. Cumhuriyet, anayasal devlet ve hukukun üstünlüğüyle tanımlanan anayasal bir rejimde meşruiyetini büyük ölçüde yitirmiştir. Fasıl 156 sayılı Yasa da öngörülebilir, belirli, açık ve net kaliteli bir yasa olmadığı gibi, buna bağlı olarak Bakanlar Kurulu'nun sokağa çıkmayı sınırlayan Emirnamesi'nin de yetki yönünden hukuka uygunluğu tartışılmalıdır. Düzenleyici işlem niteliğindeki sokağa çıkma sınırlamasına ilişkin emirnamenin yürütme organına verilen yetki bakımından anayasal boyutunu da tartışmak gerekmektir.

\section{B. Sokağa Çıkma Yasağı Yasasında Bakanlar Kuruluna Verilen Düzenleme Yetkisinin Anayasaya Uygunluğu}

Fasıl 156'nın sınırlı ve çerçeve nitelikte bir düzenleme olması, yürütmeye ise sınırsız takdir yetkisi vermesi söz konusudur. $\mathrm{Bu}$ dar ve kısıtlı çerçeve yasa

48 Ender Ethem Atay, 'Hukukta Meşruiyet Kavramı' (1997) 1(2) Gazi Üniversitesi Hukuk Fakültesi Dergisi 121, 122.

49 Hamit Görür, 'Hukuk Devletinde Meşruiyet Sorunu' (2010) Hukuk Politik <https://www.hukukpolitik.com.tr/2016/12/05/ hukuk-devletinde-mesruiyet-sorunu> Erişim Tarihi 02 Nisan 2020.

50 Atay (n 48) 127. 
biçimindeki içeriğine rağmen bu Yasa'ya dayanılarak çıkarılan Emirname yasa değer ve gücündedir. Zira Emirname, sokağa çıkma yasağı konusunda genel, soyut, konuyu ilk elden düzenleme içerir niteliktedir. İlk elden düzenleme yapma yasama yetkisinin asliliği ilkesi olarak onun bir özelliğidir.

İlgili Yasa'da (md 2) Bakanlar Kurulu'nun belirleyeceği kişilerin sokağa çıkma yasaklarından, kısacası Emirname kurallarından muaf tutulabileceği düzenlenmiştir. Bakanlar Kurulu belirleyeceği bir kişiye emirname kurallarını askıya alma veya yürürlüğünü ilan etme yetkisi verebilir. Burada idareye sınırsız bir takdir yetkisi verildiği gibi bu yetkileri de başka kişi/organlara sınırsız devri imkânı taşıyan bu düzenlemenin hukukun üstünlüğü ilkesiyle bağdaştırılması başka bir sorundur.

Fas1 156 ile içerik itibariyle gezi özgürlüğüne sınırlama getirerek, sokağa çıkmayı yasaklamak üzere Bakanlar Kurulu'na verilen emirname yetkisinin, yasama yetkisinin yürütmeye devri niteliğinde olduğu açıktır. Yasama yetkisinin genellik, aslilik ve devredilmezlik olmak üzere üç özelliği bulunmaktadır ${ }^{51}$. Yasama organın kendisine anayasayla verilen yetkileri, Anayasada açıç̧a istisna getirilmediği sürece devredilmezdir. Yürütme organı yetkisini aldığı yasadaki genel esaslar ve sınırlar içerisinde ayrıntıları düzenleyebilir. Şayet yürütme organı yasanın düzenlemediği bir konuyu ilk elden düzenliyor veya sınırları çizilmemiş bir yetkiyi kullanıyorsa yasama yetkisinin devredilmezliği ilkesine aykırılık oluşturur ${ }^{52}$. Bu yürütme organının türev niteliği ve yetkisini kullanırken mutlaka yasanın çizdiği sınırlar içerisinde kalması gerektiğine işaret eder. Bu noktada Fasıl 156'nın yürütmenin çerçevesini çizecek derinlikte ve genişlikte bir yasa olmadığı hatırlatılmalıdır.

Yasama yetkisinin genelliği, yasama yetkisinin dilediği genişlikte ve derinlikte ayrıntılı düzenleme yapılabilmesi, konu bakımından sınırlandırılmamış olması anlamına gelmektedir. Genellik ilkesi yürütmeye bırakılmış saklı bir alanının olmamasıdır ${ }^{53}$. Buna karşllık yürütme yetkisi türev ve ikincil bir niteliğe sahip olup, bu yetkinin Anayasa'ya veya yasaya dayanma zorunluluğu bulunmaktadır ${ }^{54}$.

Yasama yetkisinin asliliği, anayasaya aykırı olmamak koşulu ile anayasaya dayanma zorunluluğu olmadan yasama organının ilk elden düzenleme yapabilmesidir. Yasama yetkisinin asliliği çerçevesinde "idarenin koyacağ 1 düzenleyici kuralların idarenin, yetkisi sınırlarını aşmamış ve yasama yetkisi alanına taşmamış bulunması,

\footnotetext{
Gözler, Anayasa Hukukunun Genel Esasları ( n 22) 356.

52 Cengiz Arıkan, Türk Anayasa Hukukunda Yasama Yetkisinin Devredilmezliği İlkesi (Doktora Tezi, Ankara: Ankara Üniversitesi 2011) 117.

53 Gözler, Anayasa Hukukunun Genel Esasları ( n 22) 364.

541985 KKTC AY md 5; Harun Yılmaz, 'Türk Hukukunda Düzenleme Yetkisinin Tarihsel Gelişimi ve Niteliği' (2014) 110 Türkiye Barolar Birliği 220, $230<$ http://tbbdergisi.barobirlik.org.tr/ViewPDF- i-1345> Erişim Tarihi 10 Nisan 2020; Arıkan (n 52) 115.
} 
vazgeçilmez bir koşul" olarak kabul edilir ${ }^{55}$. Fasıl 156 'da da sokağa çıkma yasağ1 konusunda yürütmeye "yalnızca" yetki verilmesi söz konusudur. $\mathrm{Bu}$ durumda yasa koyucunun ilk-el düzenleme yetkisine taşan bir yürütme yetkisini ortaya çıkarabileceğinden anayasaya aykırılık oluşturacaktır ${ }^{56}$.

Yasama organının en temel yetkilerinden biri genel, soyut, kişilik dışı, sürekli nitelikte kural işlemler, yani yasa yapmaktır ${ }^{57}$. Ancak yasama organının uygulamadan kaynaklanan, uzmanlık gerektiren teknik konularda düzenleme yapması kolay değildir ${ }^{58}$. Yasama organının, bu tür geniş alana yayılmış yürütme organının ve/veya idarenin işlem ve eylemlerini önceden yasayla düzenlemesi de olanaksızdır ${ }^{59}$. Bu sebeple yürütme organı bireysel nitelikli somut işlemlerinin yanında genel, soyut, kişilik dışı düzenleyici işlemler de yapmaktadır. Keza yürütme organının ve idarenin yapısı gereği düzenleyici işlemler yapabilecek yetkiye sahip olduğu kabul ediliir ${ }^{60}$.

İyi bir yönetim için sadece kuralların uygulanması yeterli değildir, toplumsal ihtiyaçlarının karşılanmasına da cevap verilmelidir. Yürütme organının ve/veya idarenin yerine getirmekle yükümlü olduğu hizmetler bakımından takdir yetkisi gereklidir. Aksi halde yasamanın genel ve soyut işlemleriyle, sonradan ortaya çıabilecek sorunların çözümünde boşluk ortaya çıkabilir ${ }^{61}$. Şüphesiz yürütme organın ve/veya idarenin bu takdir yetkisi sınırsız değildir. Yasayla yürütme organına verilen yetkilerin çerçevesi konusunda farklı fikirler ileri sürülse de genel olarak kabul edilen ilke, yasayla yetki verilirken ortaya konulacak genel esasların veya temel ilkelerin, yürütmenin sınırsız takdir yetkisi kullanmasını ve keyfi hareket etmesini önleyecek nitelikte olmasıdır. Genel esasların belirlenmesi adına ilgili yasada "müdahale, yetki, şart ve şeklin" belirtilmesi gerekir. Aksi halde yasama yetkisinin devredilmezliği ile yürütmenin kanuna dayanma zorunluluğuna ilişkin ilkeler anlamsız kalır ${ }^{62}$.

Yürütmeye verilen yetkinin, genel esasları ve uyulması gereken genel kuralları belirlendikten sonra "uzmanlık ve teknik iş gerektiren hususlarda" yasama organının bu yetkiyi yürütme organına verebileceği belirtilir ${ }^{63}$. Bu kapsamda verilen yetki sınırlı

TC AYM, E 1967/41, K 1969/57, 25.10.1969.

56 Abdurrahman Eren, 'Anayasa Mahkemesinin Kanun Hükmünde Kararnamelere İlişkin İçtihadı Doğrultusunda Cumhurbaşkanlığı Kararnamelerinin Değerlendirilmesi’ (2019) 36( 1) Anayasa Yargısı 1, 21.

571985 KKTC AY md 78: 'Cumhuriyet Meclisinin görev ve yetkileri, yasa koymak, değiştirmek ve kaldırmak; Bakanlar Kurulunu ve bakanları denetlemek; Bütçe ve kesin hesap yasa tasarılarını görüşmek ve kabul etmek, para basılmasına ve savaş ilanına karar vermek, uluslararası andlaşmaların onaylanmasını uygun bulmak; kalkınma planlarını onaylamak; genel ve özel af ilanına, mahkemelerce verilip kesinleşen ölüm cezalarının yerine getirilmesine karar vermek ve Anayasanın diğer maddelerinde öngörülen yetkileri kullanmak ve görevleri yerine getirmektir'.

58 Arikan (n 52) 116.

59 Halil Kalabalık, 'İdare Hukukunda Takdir Yetkisi Kavramı Ve Benzer Kurumlarla Karşılaştırılması' (1997) 1( 2) Gazi Üniversitesi Hukuk Fakültesi Dergisi 205, 206 - 207.

601985 KKTC AY md 110/3.

$61 \quad$ Kalabalık (n 59) 207.

62 Arıkan (n 52) 117-119.

63 TC AYM, E 1993/5,K 1993/25, 06.07.1993. 
bir yetkidir ve bu sınır aşılırsa yasama yetkisi devredilmiş olur. Bu da Anayasa’ya (md 4) aykırılık teşkil eder ${ }^{64}$. Dolayısıyla yasayla yürütmeye verilecek yetkinin sinırları belirsiz olursa, yasama yetkisinin devri söz konusu olacak, bu da anayasaya aykırı olacaktır.

Yürütmenin düzenleme yetkisine ilişkin olarak, eğer yasama bir yasayla yürütme organına yetki vermişse, düzenlemeye ilişkin herhangi bir sınır çizilmemiş olsa bile, yürütmenin o yetkiyi kullanabileceği ileri sürülmüştür. Bu görüş, yasama yetkisinin devredilmezliği ve yürütme yetkisinin yasalara dayanılarak kullanması ilkelerini anlamsız kaldığı gerekçesiyle kabul görmemiştir ${ }^{65}$. Diğer bir görüşü ortaya koyan Duran'a göre; yürütmeye yasayla düzenleme yetkisi verilirken "genel esaslarının" gösterilmesi gerekir. Ancak burada genel esasların ne olduğu açık değildir, yasada sadece "müdahale, yetki, şart ve şeklin" belirtilmesi gerektiğine değinilmiştir" Güneş, yasama ve yürütme işlemlerinin birbirinden ayrılmadığını, anayasal anlamda yasama organının "temel ilkeler" ve "genel esaslar" belirleyerek yürütmeye yetki vermesinin anlaşılmaz olduğunu belirtmiştir ${ }^{67}$.

TC Anayasa Mahkemesi'nin genel görüşü ${ }^{68}$ ise yürütmeye verilen yetkinin, genel esaslar ve uyulması gereken genel kurallar belirlendikten sonra "uzmanlık ve teknik iş gerektiren hususlarda" yasama organının bu yetkiyi yürütme organına verebileceğidir. Yetki verilen yasada temel ilkelerin belirlenmesi, yani yasanın çerçevesinin yeterince sınırlandırılması ve keyfi hareket edilmesini önleyecek nitelikte olması gerekmektedir ${ }^{69}$. Dolayısıyla yasayla yürütmeye verilecek yetkinin sınırları belirsiz olursa, yasama yetkisinin devri söz konusu olacaktır.

KKTC AYM, Anayasaya aykırılığ1 iddia edilen 41/2001 sayılı KKTC Merkez Bankası Yasasına dayanılarak kabul edilen bir karara ilişkin, "yasama organının, bir konunun çerçevesini, temel ilkelerini ve sınırlarını çizdikten sonra onun ayrıntılı düzenlenmesinin yürütme organına bırakılmasının her iki organın yapısı ve işleyişi bakımından doğal ve ideal" olduğunu belirtmiştir ${ }^{70}$. TC Anayasa Mahkemesi kararlarından ve doktrininden etkilenen Mahkeme, geçmiş kararlarından hareketle yasama organının bir konunun ayrıntılarının belirlenmesi için, düzenleme yetkisini yürütme organına veya yetkilendirdiği başka bir organa verilebileceği belirtilmiştir. $\mathrm{Bu}$ gibi hallerde verilen yetkinin "yasada açıklıkla belirtilmesi, sınırlarının açıklıkla tespit edilmesi, temel ilkelerin koyulması, çerçevesinin çizilmesi ve sınırsız belirsiz bir alan bırakılmaması" gerekmektedir. Ayrıca ilgili organa keyfi hareket edecek

\footnotetext{
64 KKTC AYM, KS AM 5/97, AM 5/97 (D 1/98),1998.

${ }_{65}$ Ragıp Sarıca, 'Türkiye'de İcra Uzvunun Tanzim Selâhiyeti', (İstanbul, Türk Hukuk Kurumu Yayını, 1943), s. 259-263'den aktaran Arıkan (n 52) 118-119.

66 Duran'dan aktaran Arikan (n 52) 119.

67 Güneş'den aktaran Arıkan (n 52) 119.

68 Örneğin TC Anayasa Mahkemesi 6.7.1993 tarihli E 1993/5, K1993/25 say1lı karar.

69 Sarıca'dan aktaran Arıkan (n 52) 117.

70 KKTC AYM, KS 4/2006, 2007, 22.
} 
bir yetkinin verilmemesine özen gösterilmesi gerektiği üzerinde de durulmuştur ${ }^{71}$. $\mathrm{Bu}$ bakımdan verilen yetki sınırlı bir yetkidir ve bu sınır aşılırsa, yasama yetkisi devredilmiş olur. Bu durumda Anayasa'ya (md 4) aykırılık teşkil eder. Yasama organı anayasal çerçevede sınırsız bir yetkiyi başka bir organa devredemez.

KKTC AYM "yasama organının, bir konunun çerçevesini, temel ilkelerini ve sınırlarını çizdikten sonra onun ayrıntılı düzenlenmesinin yürütme organına bırakılmasının her iki organın yapısı ve işleyişi bakımından doğal ve ideal" olduğunu belirtmiştir ${ }^{72}$. Mahkeme, yasama organının bir konunun ayrıntılarının düzenlenmesi için, düzenleme yetkisini yürütme organına veya yetkilendirdiği başka bir organa verilebileceğini belirtmektedir. Yürütmeye verilen yetkinin "yasada açıklıkla belirtilmesi, sınırlarının açıklıkla tespit edilmesi, temel ilkelerin koyulması, çerçevesinin çizilmesi ve sınırsız belirsiz bir alan bırakılmaması" gerekmektedir. Ayrıca ilgili organa keyfi hareket edecek bir yetkinin verilmemesine özen gösterilmesi gerekir ${ }^{73}$.

KKTC AYM 2011 tarihli bir kararında, İmar Yasası'na dayanılarak çıkarılan bir emirnamenin mülkiyet hakkına, yani anayasaya aykırılığına (md 36) ilişkin başvuruyu incelemiş̧tir. Mahkeme, AY'de her ne kadar (md 11 ve 36) temel hak ve özgürlüklerin "yalnızca yasayla" sınırlanacağı hükmü olsa da yasama organının, sınırlarını çizip temel ilkeleri belirlemesi şartıyla yürütme organına ayrıntılar için yetki vermesi, oybirliğiyle yetki devri niteliğinde sayılmamıştır. Mahkeme, davaya konu emirnamenin maddi yönden incelemesini yaparak, su kaynaklarının korunması maksadı taşıyan bu düzenlemenin kamusal bir yararı temsil ettiğini belirtmiştir. Mahkeme bu gerekçelerle yetki devrinin uygun olduğuna ve temel hak ve özgürlüklere ilişkin temel ilkelere aykırılık oluşturmadığına karar vermiştir. Buna rağmen kararda yürütmenin "tasarruflarda bulunabilmesi için, ... Yasada esaslarını saptaması, amacı belirlemesi, alınacak önlemlerin gereksinimlere uygunluğunu sağlamak üzere" yürütmenin görevlendirilmesi gerektiği belirtilmiştir ${ }^{74}$.

Sonuç olarak yasama organ1, yürütmeye belirli bir konuda yetki verecekse; yukarıda ifade edilen genel esasların belirlenmesi koşuluyla uzmanlık ve idare tekniğine ilişkin hususların düzenlenmesi için hükümete yetki verebilmesi gerekir. Anayasa uyarınca yasayla düzenlenmesi zorunlu olan konularda, münhasır yasa alanlarında, yürütmeye düzenleme yetkisinin tanınmaması ve sübjektif hakların düzenlenmesinin yürütmeye bırakılamamas1 ilkelerine uyulmas1 da gerekir ${ }^{75}$. Somut olayda ise Cumhuriyet Meclisi'nin sokağa çıkma yasağı konusunda Bakanlar Kurulu'na yetki verilebileceği ve Bakanlar Kurulu'nun da bu yetkiye dayanarak düzenleyici işlemler yapabileceği

\footnotetext{
KKTC AYM, KS 4/2006, 28. KKTC AYM, KS (D 3/2012), 2012, 25. KKTC AYM, KS AM 5/97.

2 KKTC AYM, KS 4/2006, (D 1/2007), 2007, 22.

73 KKTC AYM, KS 4/2006, (D 1/2007), 2007, 28; KKTC AYM, KS (D 3/2012), Birleştirilmiş 12-13-14-15-16/2012 (D 3/2012), 2012, 25.

74 KKTC AYM, KS 21/2009, 21/2009 (D 3/2011), 2011, 12-13.

75 Selim Kaneti, 'Anayasa Mahkemesi Kararlarına Göre Yasama Yetkisi İle Yürütmenin Düzenleme Yetkisinin Sınırları' (1994) 54(1-4) İstanbul Üniversitesi Hukuk Fakültesi Mecmuası 33, 33 vd.
} 
sonucu ortaya çıkmaktadır. Ne var ki Fasıl 156'da Bakanlar Kurulu'na sadece yetki verilmiş, ancak bu yetkiye dayanılarak yapılacak işlemlerin temel ilkeleri, esasları veya sınırları belirlenmemiştir. Yasa, salgın hastalık sebebiyle sokağa çıkma yasağı getirilebileceğini dahi öngörmemektedir. Dolayısıyla Anayasanın 4. maddesi uyarınca bir yetki devri söz konusudur. Bu bakımdan Yasaya bağlı olarak kabul edilen sokağa çıkma yasağına ilişkin emirnamelerin de anayasaya uygunluğundan söz edilemez. Bu noktada yukarıda ifade edilen AİHM standartlarında öngörülen kaliteli bir yasadan söz etmek mümkün görünmemektedir.

\section{Emirnamelerin Anayasaya Uygunluk Denetimi}

Yukarıda ifade edilen mevzuat içerisinde şüphesiz denetim açısından incelenmesi gereken işlemler emirnamelerdir. Emirnamelerin anayasal denetimi hususunda ilk olarak KKTC anayasa yargısında, KKTC AYM'nin diğer yetkileri yanında, iptal davası yoluyla denetim, itiraz (havale) yoluyla denetim ve Cumhurbaşkanı'nın yasa ve meclis kararlarının ön denetim yoluyla denetiminde yetkili olduğunu belirtmek gerekir $^{76}$.

AYM'de; yasa, kararname, tüzük, Cumhuriyet Meclisi İçtüzüğü, Cumhuriyet Meclisi kararları ve yönetmeliklere karş1 iptal davası açılabilir ${ }^{77}$. İptal davası yoluyla düzenleyici işlemler de denetlenmekte ancak AYM, Bakanlar Kurulu'nun kararları veya emirnamelerine karşı 147. maddenin lafzından hareketle iptal davası açılamayacağına karar vermiştir ${ }^{78}$. Mahkemeye göre maddede geçen "karar" sözcügünden Bakanlar Kurulu kararı değil, Cumhuriyet Meclisi kararı anlaşıldığı açıktır. Ona göre anayasa koyucu başka tür kararların da denetimini öngörmüş olsaydı sadece "karar" ibaresi kullanırd1 ${ }^{79}$. Mahkeme emirnamelerin, Bakanlar Kurulu kararı niteliğinde kabul edilmesi gerektiğini belirtmiştir ${ }^{80}$. Dolayısıyla anayasaya aykırı oldukları gerekçesiyle bu emirnameler, AYM'de iptal davasına konu olamayacaktı. KTFD döneminde AYM'ye yapılan bir başvuruda, 1975 tarihli Askeri Yasak Bölgeler Emirnamesi’nin gezi ve yerleşme özgürlüğüne aykırı olduğu, "kaynağını herhangi bir yasadan almadığı nedeni ile Anayasaya aykırı olduğu iddia" edilmiştir. Mahkeme "Herhangi bir emirnamenin yasal olup olmadığı konusu Anayasa kurallarını ilgilendiren bir konu değil" demiştir. Ona göre "böyle bir konu ancak alelâde yasa

\footnotetext{
76 Demet Çelik Ulusoy, 'Kıbrıs'ta Anayasa Yargısı ve Bireysel Başvuru' (2017) <doi:https://anayasatakip.ku.edu.tr/wpcontent/uploads/sites/34/2017/10/Demet-CCCA7elik-Ulusoy-KC4B1brC4B1sE28099ta-Anayasa-YargC4B1sC4B1-veBireysel-BasCCA7vuru1.pdf> Erişim Tarihi 19 Nisan 2020.

771985 KKTC AY md 147(1): 'Cumhurbaşkanı, Cumhuriyet Meclisinde temsil edilen siyasal partiler, siyasal gruplar ve en az dokuz milletvekili veya kendi varlık ve görevlerini ilgilendiren alanlarda diğer kurum, kuruluş veya sendikalar bir yasanın, kararnamenin, tüzüğün, Cumhuriyet Meclisi İçtüzüğünün, Cumhuriyet Meclisi kararının, yönetmeliğinin veya bunların herhangi bir kuralının Anayasanın herhangi bir kuralına aykırı veya ona uygun olmadığı gerekçesi ile Anayasa Mahkemesinde doğrudan doğruya iptal davası açabilirler.'

78 Can Azer, 'KKTC'de Düzenleyici İșlemlerin Denetlenme(me)si Sorunu ve Buna Çözüm Yolu: İyi İdare Yasası' (2018) 32(142) Türkiye Barolar Birliği Dergisi 429, 437 <http://tbbdergisi.barobirlik.org.tr/m2019-142-1854> Erişim Tarihi 21 Mart 2020.

79 KKTC AYM, KS 23/85 (D 8/87), 04.06.1987.

${ }^{80}$ KKTC AYM, KS 7/89 (D 6/89), 30.06.1989.
} 
kurallarını ve hukuk ilkelerini ilgilendirmektedir. Bu konular hakkında da karar verme yetkisi davaya bakan mahkemelerindir" ve bağlamda başvuru reddedilmiştir ${ }^{81}$.

Kararlar ifadesinin yalnızca AY'nin 147. maddesinde sayılmış olan kararname, tüzük ve yönetmelikleri değil, bunların dışında kalan düzenleyici işlemleri kapsadığg da belirtilebilir ${ }^{82}$. Nitekim KKTC AYM'sinin hem 147. maddede geçen tüzüğün hem de maddede sayılmamış diğer düzenleyici işlemlerin itiraz yoluyla denetlenmesine dair kararları da vardır ${ }^{83}$.

AYM daha sonraki başka bir kararının karşı oyunda, emirname adı altında yapılmış bir işlemin “....tüzük olduğunun kesin bir şekilde anlaşılması halinde bu tür bir düzenlemenin emirname ismi altında yayımlanmasına bakılmaksızın anayasal yargı denetimine tabi" tutulabileceğine değinmiştir ${ }^{84}$. Bu değerlendirmeye göre AYM işlemin adıyla kendisini bağlı görmemekte, hukuki nitelendirmeyi kendisi yapmaktadır. Mahkeme, emirnameleri, iptal davasına konu olabilecek düzenleyici işlemlerden biri olarak görmesi halinde dava konusu olabileceğini belirtmiştir ${ }^{85}$.

1995 tarihli bu kararın karşı oyunda tüzük veya yönetmelikleri başka bir hukuk sistemine ait bir sözcük ile niteleyerek onları iptal davası konusu olmaktan çıkarılmasının Anayasa'ya aykırı olacağı ifade edilmiştir. Adsız düzenleyici işlemlerin adları her ne olursa olsun bunları "yönetmelik" biçiminde kabul ederek bu işlemin hukuki rejimine tabi tutulmaları gerekir ${ }^{86}$.

Anayasa yargisında bir diğer denetim yolu olan somut norm denetimine (AY md 148/1) göre ${ }^{87}$ “...herhangi bir mahkeme işlemindeki bir taraf, ... bu işlemdeki uyuşmazlık konularından herhangi birinin karara bağlanmasında etkisi olabilen herhangi bir yasanın veya kararın..." anayasaya aykırılığı iddiasında bulunabilirler. Maddede geçen "karar" ibaresiyle, soyut norm denetimine konu olan düzenleyici işlemler dışında kalan diğer düzenleyici işlemler anlaşılabilir. Dolayısıyla itiraz yoluna ilişkin bu maddede geçen "karar" AYM tarafindan daha geniş yorumlanarak, hem 147. maddede sayılanlar hem de diğer düzenleyici işlemler biçiminde nitelendirilmiş, bu

\footnotetext{
KTFD AYM, KS 18/78, 27.04.1979.

82 Tufan Erhürman, Yüksek İdare Mahkemesi'nin Görev Alanı (1. Bası, Işık Kitabevi, Lefkoşa, 2013) 214.

83 Azer çalışmasında AY'nin 148. Maddesinde geçen denetime konu işlemlerin, yine AY'nin iptal davasına ilişkin 147. Maddesinde geçen düzenlemeden farklı olarak, tüzük, kararname ve yönetmelik biçiminde sayılmadığına, 148'de sadece yasa ve kararlardan söz edildiğinden "kararlar" dan ne anlaşılacağına ilişkin değerlendirmesini aktarmaktadır. Azer (n 78) 439.

${ }^{84}$ KKTC AYM, KS 9/93 (D 5/95), 29.06.1995

$85 \quad$ Azer (n 78) 437.

86 Özay (n 16) 383.

${ }^{87} 1985$ KKTC AY md 148(1): ‘ İstinaf işlemleri de dâhil olmak üzere, herhangi bir mahkeme işlemindeki bir taraf, bu işlemin herhangi bir safhasında bu işlemdeki uyuşmazlık konularından herhangi birinin karara bağlanmasında etkisi olabilen herhangi bir yasanın veya kararın veya söz konusu yasa veya kararın herhangi bir kuralının Anayasaya aykırılığını ileri sürebilir ve bunun üzerine, mahkeme bu konuyu, Anayasa Mahkemesine sunar ve bu konu hakkında Anayasa Mahkemesince bir karar verilinceye kadar söz konusu işlemi durdurur.

Ancak Anayasa Mahkemesince herhangi bir yasanın veya kararın veya söz konusu yasa veya kararın herhangi bir kuralının Anayasaya aykırılığı konusunda aynı veya benzeri bir konuda daha önce karar verilmişse, mahkeme konunun Anayasa Mahkemesine iletilmesinin reddine karar verebilir.'
} 
işlemleri bireyler lehine olacak biçimde daha geniş tutmuştur ${ }^{88}$. Ancak itiraz yoluyla yapılan denetim için AY'de ifade edilen diğer şartların da gerçekleşmesi gerekir (md 148). Bazı şartların gerçekleşmemesi halinde AYM başvuruları reddedebilmektedir ${ }^{89}$. Ayrıca AYM'nin itiraz yolunda verdiği anayasaya aykırılık kararı sadece tarafları bağlayıcı nitelikte verebilir ${ }^{90}$. Mahkeme isterse aykırı bulunan kuralın, herkes için bağlayıcı nitelikte olmasına da karar verebilir ${ }^{91}$.

AYM emirnameleri iptal davasına konu olabilecek işlemler arasında görmemiş olsa da bunların birçok açıdan KKTC hukukuna yayıldığını belirtmek gerekir. Önceki kararlarda değinilen hukuki nitelendirme konusundaki hassasiyetler yerindedir. Yukarıda da gördügümüz gibi AYM itiraz yolu ile önüne gelen davalarda tüm düzenleyici işlemleri karar olarak nitelendirerek kabul etmektedir ${ }^{92}$. Emirnamelerin iptali konusunda bir diğer yöntem şüphesiz idari yargı denetimidir. Emirname gibi düzenleyici işlem veya kararlar, kişi haklarını olumsuz etkilemeleri sebebiyle idarenin yargısal denetimi söz konusu olacaktır ${ }^{93}$. İyi İdare Yasası'na göre ( $\mathrm{md} 2$ ) “düzenleyici işlem", idarenin genel ve soyut kurallar koyan idari işlemleridir. Yasa uyarınca tüm idari işlemlere karşı YIMM'de yetmiş beş gün içerisinde iptal davası açılabilir (md 19). Emirnamelerin denetlenmesinin önü İyi İdare Yasası kapsamında mümkün olmakta, bu denetimi ise KKTC YİM üstlenmektedir. Bu Yasa yürürlüğe girene kadar, KKTC YIM'in çok sayıda düzenleyici işlemi denetlemekten kaçınmış, aynı yaklaşımın tüzük ve yönetmelik gibi düzenleyici işlemleri kural olarak anayasaya uygunluk denetimini gerçekleştiren KKTC AYM'si tarafından da ortaya konulmasıyla, KKTC'de emirnameler özelinde bazı düzenleyici işlemlerin denetlenememesi sorununu ortaya çıkmıştır ${ }^{94}$. KKTC YIMM verdiği kararların önemli bir kısmında, KKTC idare hukukunun Kıta Avrupası ve Anglo-Sakson hukuk sistemlerinin hâkim olduğu karma bir hukuk sistemi olduğu yönündedir. Bu bağlamda düzenleyici işlemlerin de Anglo Sakson hukuk sisteminde denetlenemediği gerekçesi kararlarında yer almıştır ${ }^{95}$.

KKTC'de belirli bir dönem hem idari yargının hem de anayasa yargısının görev alanına girmediği yargı organlarınca ileri sürülen düzenleyici işlemler söz konusu

\footnotetext{
88 Azer (n 78) 439-440.

89 KKTC AYM, KS D 3/2016- 15/2015, 07.04.2016; KTFD AYM, KS D 1/82, D 1/82, Yargitay/Asli Yetki İstinaf 1/82, 01.06.1982.

90 Çelik Ulusoy (n 76) 16.

911985 KKTC AY md 148(3): 'Anayasa Mahkemesinin, bu maddenin (2). fikrası gereğince verdiği herhangi bir karar, konuyu sunan mahkemeyi ve ilgili tarafları bağlar. Alınan karar, yasanın veya kararın veya söz konusu yasa veya kararın herhangi belli bir kuralının Anayasaya aykırı olduğu yolunda ise, söz konusu yasa veya karar veya söz konusu yasa veya kararın herhangi belli bir kuralı, Anayasa Mahkemesince aksine karar verilmedikçe yalnız söz konusu mahkeme işlemine uygulanmaz.'

92 Azer (n 78) 445 .

93 Necatigil (n 13) 191.

94 Azer çalışmasında tamamıyla bu soruna işaret etmektedir. Yazar, KKTC AYM'sinin de kararname, tüzük ve yönetmelik dışında kalan düzenleyici işlemlere karşı açılan iptal davalarını reddetmiş olduğu ve bu durumda da hiçbir yargı organının anayasaya uygunluk bakımından denetlenemediği düzenleyici işlemler kategorisinin ortaya çıktığı eleştirisini yapmaktadır. Azer (n 78) 446, 449. 27/2013 Sayılı İyi İdare Yasas1, Kanun Numaras1: 27/2013, Kabul Tarihi:11.11.2013, md $13<$ https:// www.mahkemeler.net/birlestirilmis/27-2013.doc> Erişim Tarihi 10 Ocak 2020

95 KKTC YIM, KS 81/2007, D 4/2009, 27.02. 2009
} 
olmuştur. Bunların odağında şüphesiz emirnameler gelmekte, yargının bu yaklaşımı neticesinde hukuk devletinde yargı eliyle denetim dışında bırakılan işlemler söz konusu olmaktaydi. Hukuk devleti ilkesiyle bağdaşmayan bu ciddi sorunu ilk kez ele alan Erhürman, YİM ve AYM kararları 1şı̆ı̆ında İngiliz hukuk sisteminden etkilenerek KKTC'de düzenleyici işlemlerin, "ikinci derecede yasal mevzuat" veya Karanhanoğulları'nın belirttiği gibi "ikincil yasama" olarak kabul edildiklerine işaret etmektedir ${ }^{96}$. Yazar yargı organlarının ret kararları ve o döneme yapılan sınırlı yorumlardan hareketle, ilgili düzenleyici işlemlerin "yasa" niteliğinde oldukları gerekçesiyle idari yargı denetiminin dışında bırakıldığının altını çizmiştir. Hâlbuki İngiliz hukuk sisteminde bu tür işlemlerin fonksiyonel anlamda yasama işlemi niteliğinde oldukları ve bu kabulün ikincil yasama (secondary legislation) niteliğindeki bu işlemlerin denetlenmemesi sonucunu doğurmayacağını açıklamıştır ${ }^{97}$. Yarg1 organının verdiği kararların aksine İngiltere'de delegated legislation, subordinate legislation, secondary legislation ${ }^{98}$ gibi kavramlarla ifade edilen işlemler yasamanın "primary legislation" yani ilk-el işlemlerinden ayrıdır. İngiltere'de parlamentonun üstünlüğü ilkesi çerçevesinde denetlenmeyen "legislation" yasamanın "primary legislation" yani ilk-el işlemleridiri".

Somut olayda Bakanlar Kurulu'nun sokağa çıkma yasağına ilişkin genel, soyut ve sürekli nitelikteki bu düzenleyici işlemin denetlenerek iptali söz konusu olmalıdır. Bunun dışında işlemin anayasaya aykırılık bakımından somut norm denetiminin konusu olacağı açık olmakla birlikte, Emirname kapsamında özellikle sokağa çıkma yasağına riayet etmeyenlere uygulanan yaptırımların yargısal denetiminin de söz konusu olacaktır. İleriki başlıkta anayasaya aykırılık yönünden incelenecek olan 8/2020 sayılı YGK da anayasaya uygunluk denetimine tabidir. YGK ile öngörülen yaptırımların iptali için YİM'de dava açılması ve emirnamelerin bu yolla somut norm denetimine konu olması mümkündür Dolayısıyla ileriki tarihlerde bu emirnameler hakkında Anayasa'ya aykırılık iddiası gündeme gelebilir.

96 Yazar çalışmanın başında bizim de dikkatini çektiğimiz hukuk işlemlerinin birbirinden ayrılmasında kullanılan maddi ve şekli kriter ayırımına değinmiştir. Buna göre İngiliz Hukukunda yasalar içeriksel (maddi) yönüyle tanımlanır ve yürütmenin yaptığı her kural koyma yasama (düzenleme) sayılmaktadır. Onur Karahanoğulları, 'İngiliz Hukukunda İkincil Yasama' (1995), AÜSBF, 03 (50), 3 vd. < https://dergipark.org.tr/en/download/article-file/36423> Erişim Tarihi 16 Mart 2020.

97 Tufan Erhürman, Kuzey Kıbrıs Türk Cumhuriyeti İdari Yargılama Hukuku, (1. Bası, Işık Kitabevi, Lefkoşa, 2012) $141 \mathrm{ff}$.

98 Delegated legislation, subordinate legislation, secondary legislation gibi kavramların kullanıldığına işaret eden Karahanoğulları, Türk hukukunda "sırf yürütmece yapıldığı için "idari" olarak kabul edilen yürütmenin düzenleme tasarruflarının İngiltere'de yasama kategorisine dâhil edildiğini de belirtmiştir. Karahanoğulları, (n 94) 228.

99 Hemen belirtmek gerekir ki Erhürman bahse konu sorunu ele aldığı çalıșmalarda, Avrupa Konseyi Bakanlar Komitesi’nin İyi İdare Konusunda Üye Devletlere CM/REC (2007) Sayılı Tavsiye Kararı"na eklenen İyi İdare Yasasının Avrupa idare hukukundaki gelişmeleri ortaya konulması bakımından incelemiştir. Bu belgenin aydınlatıcı olması ümidiyle değerlendirdiği çalışmada yargı organlarının İngilizce metinleri aktarırken daha dikkatli yorum yapmaları gerektiğine işaret etmiştir. Erhürman (n 95) 146. Erhürman, çalışmalarından kısa bir süre sonra milletvekili olarak KKTC Cumhuriyet Meclisi'ne girmiştir. Bu kapsamda öncülüğ̈̈nde ilk yapılan Yasa 27/2013 sayılı İyi İdare Yasası'dır. Bu Yasa yürürlüğe girdikten sonra YIM düzenleyici işlemlerin denetimini açıkça üstlenmiştir. 


\section{Sokağa Çıkma Yasağının Yaptırımı ve Yasa Gücünde Kararname Rejimi}

Sokağa çıkma yasağının eski bir Yasa olarak Fasıl 156'daki biçimiyle caydırıcı bir yaptırımı bulunmamaktaydı. Nitekim Yasa güncelliğini oldukça yitirmişti. Bakanlar Kurulu, durumun hassasiyeti ve aciliyetini göz önünde bulundurarak, Fasıl 156'nın suç ve cezalara ilişkin (md 4) yaptırım hükmünün ${ }^{100}$ güncellenmesine ihtiyaç duyulduğunu belirtmiştir. Bakanlar Kurulu'nun kararname çıkarma yetkisi için bir yasayla önceden yetkilendirilmesine gerek yoktur. Kısmi sokağa çıkma sınırlamasına ilişkin emirname "yürürlükte kaldığı sürece asgari ücretin \%10’u oranında artırılması amaciyla" hazırlanan 8/2020 Sayılı YGK ${ }^{101}$, AY'deki Bakanlar Kurulu'nun kararname çıkarma yetkisinden hareketle yapılmıştır. Ancak AY'ye göre Bakanlar Kurulu, "ekonomik konularda" ve "ivedilik" halinde kararname çıkarabilir (md 112) ${ }^{102}$. Dolayısıyla sadece aciliyeti olan ekonomik konularda YGK çıkarabilir. Bu noktada 8/2020 sayılı YGK'nın ivedi bir konuya ilişkin olduğu ifade edilse bile aciliyeti olan ekonomik bir konuda düzenleme içermediği açıktır ${ }^{103}$.

Yüksek Mahkeme YGK'lara ilişkin denetiminde AY'deki (md 112) iki koşulu oldukça ihtiyatlı değerlendirmektedir. Mahkeme; (1) konunun ekonomik olması ve (2) ivediliğin varlığı koşullarının tatmin edilmesi gerektiğini belirtmektedir. Ekonomik konuların nasıl yorumlanacağına ilişkin ise "kararnamenin konusunun doğrudan ve sıkı sıkıya ekonomi ile bağlantılı olması gerektiği, ekonomi ile dolaylı ve uzak olan ilişkilerin yeterli olmadığı" kanısındadır. Mahkeme kararlarında YGK'lara ilişkin "yasaklanan alan"lar olduğuna, "mali yükümlülükler getirilemeyeceği”" ve "kişisel ve siyasal hak ve özgürlüklerin kısıtlanamayacağına" (AY md 112/4) ${ }^{104}$ açıkça işaret etmiş̧ir. Mahkeme zorunluluk nedeniyle yapılmış bir YGK'y1 incelemiş, "Anayasa'ya aykırı olan bir düzenlemeyi zaruret/zorunluluk ilkesi ışığında geçerli kabul etmekten" kaçınılması gerektiğine ve zorunluluk ilkesi için "fevkalade istisnai

\footnotetext{
100 Fasıl 156 md 4: '2.madde uyarınca yapılan Emirname kurallarına aykırı bir davranışta bulunan herhangi bir kişi bir suç işlemiş olur ve bir yıla kadar hapis cezasına veya yüz Kıbrıs Lirasına kadar para cezasına veya her iki cezaya birden çarptırılabilir'.

101 Sokağa Çıkma Yasağı Yasası Hakkında Yasa Gücünde Kararname, Kararname Sayı: 8/2020 E.T(K-I) 488-2020 RG 25 Mart 2020/S 50/sayfa 127. KKTC Başbakanlık Basımevi (25.03.2020) 27-28<https://basimevi.gov.ct.tr/> Erişim Tarihi 25 Mart 2020.

102 KKTC AY md 112/1: 'Ekonomik konularda, ivedilik varsa, Bakanlar Kurulu yasa gücünde kararname çıkarabilir. Yasa gücünde kararname, Resmî Gazete'de yayımlanarak yürürlüğe girer ve aynı gün, gerekçesi ile birlikte Cumhuriyet Meclisine sunulur'.

103 8/2020 Sayılı Yasa Gücünde Kararname md 4: Sokağa Çıkma Yasağı Yasası'nın 2. maddesi uyarınca yapılan Kısmi Sokağa Çıkma Yasağı Emirnamesi'ne aykırılık halinde yaptırım öngörmektedir. Buna göre Emirname "kurallarına aykırı bir davranışta bulunan herhangi bir kişi bir suç işlemiş olur ve bir yıla kadar hapis cezasına veya asgari ücretin \%10 (yüzde on)'una kadar para cezasına veya her iki cezaya birden çarptırılabilir'. Fasıl 156 (n 6); 202 Sayılı Kısmi Sokağa Çıkma Yasağı Emirnamesi (n 5).

104 KKTC AY md 112(4): ‘Bu maddede öngörülen yasa gücünde kararnameler ile, yeni mali yükümlülükler getirilemez, kişisel ve siyasal hak ve özgürlükler kisitlanamaz’.
} 
ve kaçınılmaz olarak zorlayıcı şartların varlığı ve başvurulabilecek başka bir çare olmaması" koşullarının bulunması gerekliliğine işaret etmiştir ${ }^{105}$.

Burada dikkati çeken ilk husus; gezi ve yerleşme hürriyetine getirilen sınırlamanın esaslarının, çerçevesinin, koşullarının, sınır ve istisnalarının Emirname ile öngörülmüş olması ve buna ilişkin yaptırım konusunda YGK çıkarılmış olmasıdır ${ }^{106}$. Bir kere gezi ve yerleşme özgürlüğü Anayasa'nın kişi hakları kısmında düzenlenmektedir. Bu hususta hem emirname hem de YGK ile doğrudan ya da dolaylı düzenleme yapılması Anayasa'ya aykırılık teşkil eder. Bir diğer husus; YGK'nın organik anlamda yürütme fonksiyonel anlamda yasama işlemi sayılmasından kaynaklanabilir. KKTC AY'sine göre Bakanlar Kurulu kararname çıkarma yetkisini Anayasa'dan almakta, yasama organından ayrıca yasayla kararname çıkarma konusunda yetki almamaktadır. Dolayısıyla bu kararnameler "kanun kuvvetinde kararname" niteliğinde değildirler. Teziç, yasama organının, bir kanunla, belli konularda yürütmeye verdiği geniş düzenleme yetkisi üzerine Bakanlar Kurulu'nca bu tür kararnamelerin çıkarılabileceğini belirtmiştir. Bunların kanun kuvvetinde olmaları, yürürlükteki şeklî kanunları değiştirebilmesini ifade eder ve bu tip kararnamelerin diğer bir özelliği, yürütme organının kararnameyle düzenlediği hususların ayrıca belli bir süre içinde yasama organının onayına sunulmasıdır ${ }^{107}$. Bahse konu YGK Cumhuriyet Meclisi'nin onayına sunulmakta ve meclis bu kararnameler üzerindeki onay yetkisini yasa biçiminde kullanmaktadır. Bu noktada YGK'nın hüviyeti değişmektedir. İçinde bulunduğumuz süreçte de Bakanlar Kurulu tarafindan kabul edilen YGK'lar Cumhuriyet Meclisi'nin bugünlerde gündemindedir. Bu bilgiler 1şı̆̆ında 8/2020 Sayılı YGK'nın Fasıl 156 sayılı Yasa'da değişiklik meydana getirmesi açısından ekonomik bir konuya ilişkin boyutu olmadığı gibi, kişi haklarına ilişkin dolaylı bir yaptırım öngörmesi nedeniyle tartışmalıdır.

Suç ve cezada yasallık ilkesini dar yorumlayanlar, bir yasak davranışı belirleyerek suç ve ceza oluşumunun, temel hak ve özgürlüklerin sınırlanması mahiyetinde olduğunu belirterek ancak yasayla yapılması gerektiğini savunur ${ }^{108}$.Aksi halde yürütme organına verilecek böyle bir düzenleme yetkisi yasama yetkisini devredilmezliği ilkesine aykırılık oluşturacaktır. İlkeyi geniş yorumlayanlar ise, yasanın çizdiği belirli bir çerçeve dâhilinde kalmak kaydıyla yürütme organına suçun teşkili için verilen yetkinin Anayasaya aykırı oluşturmayacağı görüşündedirler ${ }^{109}$. Buna göre toplum hayatının hızlılığı, yasa koyucunun değişiklikleri takip etmesi ve fiili suç

\footnotetext{
105 KKTC AYM, KS D 2/2012, D 2/2012, Birleştirilmiş Anayasa Mahkemesi: 20 ve 21/2012, 16.08.2012. Ayrıca; KKTC Hukukunda zorunluluk ilkesine ilişkin bir değerlendirme için bkz Çelik Ulusoy D, ‘Kuzey Kıbrıs Türk Cumhuriyeti’nde Cumhurbaşkanlığı Seçimlerinin Ertelenmesi ve Cumhurbaşkanının Göreve Devamına İlişkin Parlamento Kararının Yarattığı Anayasal Sorunlar' (2020) 22(2) Dokuz Eylül Üniversitesi Hukuk Fakültesi Dergisi.

106202 Sayılı Emirname'nin 3. md 'Bu kısmi sokağa çıkma yasağına uymayanlar hakkında yürürlükteki mevzuat çerçevesinde cezai kovuşturma yapılacaktır'.

107 Erdoğan Teziç, 'Yasama Yetkisi ve Kanun Hükmünde Kararnameler' (1972) 5 (3) Amme İdaresi Dergisi 3, 3 vd.

108 Arikan (n 52) 131.

109 ibid 132.
} 
sayıp yasaya koyması, yapısı ve yoğun çalışması nedeniyle imkânsızdır. Ancak bu türden bir yürütme yetkisinin sadece tüzük ve yönetmelik ile mümkün olabileceği, diğer düzenleyici işlemlerle mümkün olamayacağı belirtilir. Burada sadece suçların yürütme organınca belirlenebilmesi ileri sürülmüş, cezaların belirlenmesi kabul edilmemiştir. Cezaların mutlaka önceden yasayla belirlenmesi gerekir ${ }^{110}$.

Kararnameyle yapılan bu değişiklik Anayasa' yla ${ }^{111}$ çelişmektedir. Keza kararnamelerle hangi konularda karar alınabileceği belirtilmiş yani konu bakımından sınırlandırılmıştır. Anayasa'nın hiçbir hükmünde kararnameyle ceza koyulabileceğine ilişkin bir hüküm yoktur. Ayrıca genel ilke olarak yürütme organı ve/veya idare yeni bir idari suç ve ceza yaratamayacağı, idari suçlar bakımından da yasallık ilkesinin geçerliliği belirtilmelidir ${ }^{112}$. Ceza hukukunun temel ilkelerinden olan yasallık, hangi eylemlerin önceden suç sayılacağının yasa ile belirlenmesi (suçta yasallık) ve bir suç işleyenlerin önceden hangi yaptırıma tabi olacaklarının yasa ile belirlenmesidir (cezada yasallık) ${ }^{113}$. Bu ilkenin temeli, kişiler için önceden yasak davranışların belirlenmesi sonucu kişi özgürlüklerinin sınırını belirlemektir ${ }^{114}$. Suçta ve cezada yasallık evrensel ilkesi, suçların ve cezaların yasayla öngörüleceği, yürütmenin herhangi bir düzenleyici işlemiyle (yönetmelik, tüzük, kararname) öngörülemeyeceğine dönük temel hukuk prensibidir. YGK, her ne kadar Fasıl 156'nın yaptırımına ilişkin değişiklik meydana getirse de hukuki güvenlik ilkesi gereği öngörülebilir olmayan bir Yasa'da bu şekilde getirilen değişikliğin de Anayasaya uygun olmadığı belirtilmelidir. Salgın hastalık sürecinde, anayasaya göre hak ve özgürlüklerin sınırlanmasının asıl belirleyicisi olan parlamentolar etkisiz organlar haline dönüşmüştür. Bundan sonraki süreçte devletin tüm organlarının etkili katılımının sağlandığı "kriz dönemi” düzenlemeleri üzerinde çalışılması gerekmektedir.

\section{Sokağa Çıkma Yasağının Temel Hak ve Özgürlükler Rejimi Çerçevesinde Değerlendirilmesi}

Yukarıda Bakanlar Kurulu'nun sokağa çıkma yasaklarına ilişkin yetkisinin dayanağı olan Fasıl 156 ve buna bağlı olarak oluşturulan emirnameler incelenmiş, Bakanlar Kurulu'nun bu sınırlamalara ilişkin yetkilerinin "kaliteli bir yasaya" dayanması gerektiği belirtilmiştir. Yasa ve buna bağlı sokağa çıkma yasağına ilişkin emirnamelerin; Anayasa'nın gezi ve yerleşme özgürlüğüne ilişkin 22. md hükmüne ${ }^{115}$

\footnotetext{
110 ibid 134

111 1985 KKTC AY md 18/1 ve 112/1.

112 Ezgi Aygün Eşitli, 'Suçların ve Cezaların Kanuniliği İlkesi' (2013) 104 TBB Dergisi 226,235<http://tbbdergisi.barobirlik. org.tr/m2013-104-1249> Erişim Tarihi 19 Nisan 2020.

113 Arikan (n 52) 130.

114 Eşitli (n 112) 226.

1151985 KKTC AY md 22(1): 'Her yurttaş, gezi özgürlüğüne sahiptir; bu özgürlük ancak ulusal güvenliği sağlama ve salgın hastalıkları önleme amaçlarıyla ve yasa ile sınırlanabilir'. Maddenin devamında; '(2) Her yurttaş, dilediği yerde yerleșme özgürlügüne sahiptir, bu özgürlük, ancak ulusal güvenliği sağlama, salgın hastalıkları önleme, kamu mallarını koruma, sosyal, ekonomik ve tarımsal gelişmeyi ve sağlıklı kentleşmeyi gerçekleştirme zorunluluğuyla ve yasa ile sınırlanabilir. (3) Her yurttaş, yurda girme ve çıkma özgürlüğüne sahiptir. Yurt dışına çıkma özgürlüğü yasa ile düzenlenir. (4) Hiçbir yurttaş, isteği dışında Devlet sınırları dışına çıkarılamaz ve aynı şekilde girmekten alıkonulamaz' düzenlenmiştir.
} 
ve temel hak ve özgürlüklerin olağan dönemde sınırlamasına ilişkin genel hükmüne göre irdelenmesi gerekir (md 11) $)^{116}$.

KKTC AY'si temel hak ve özgürlüklerin sınırlanması rejimi bakımından, bazı farklılıklar olsa da TC 1961 Anayasası'ndaki kademeli sınırlama rejimine benzemektedir ${ }^{117}$. Kademeli sınırlama rejimine göre, sınırlama sebebi özel olarak öngörülmüş maddelerde (örneğin md 22) nitelikli yasa kaydı söz konusudur. $\mathrm{Bu}$ özgürlüklere getirilecek sınırlamalar sadece bu maddelerde öngörülen özel sınırlama sebeplerine dayanmalıdır. Hiçbir sinırlama sebebi öngörülmeyen maddeler, (örneğin md 23/1 $)^{118}$, mutlak hak kategorisi içerisinde kabul edilmektedir. Bu çerçevede bir diğer kategori ise, sınırlama sebebi öngörülmeyip sadece "yasayla" sınırlama kaydının bulunduğu basit yasa kaydıdır. Bu tür hak ve özgürlüklerin (örneğin md 21/2) ${ }^{119}$ sinırlanması bakımından yasa koyucunun, AY'deki genel sinılama sebeplerine (md 11) dayanması mümkündür. AY'de sınırlamaların yasayla yapılacağı sıklıkla tekrarlanmakta ancak bazı maddelerde ne yasayla sınırlama ne de sınırlama sebeplerine rastlanmamaktadır. Nitelikli yasa kayitlarında yer alan nedenlerden bir kısmı, genel sınırlama sebeplerinin (md 11) tekrarı niteliğindedir ${ }^{120}$.

KKTC AYM Anayasa'daki hak ve özgürlüklerin mutlak ve sınırsız olmadığı, bu hakların anayasa maddelerinde belirtildiği şekilde veya Anayasa'nın genel sınırlama maddesinde belirtildiği gibi yasalar ile kısıtlanabileceği görüşündedir. Anayasa'daki bazı hak ve yasaklamalar açık bir şekilde ifade edilmekte, bunların 11. maddedeki genel sınırlama sebeplerine bağlı olarak sınırlandırılmasının söz konusu olamayacağına işaret edilmektedir ${ }^{121}$.

Anayasa'da, gezi ve yerleşme özgürlüğünde olduğu gibi, nitelikli yasa kaydı türündeki bazı hak ve özgürlüklerin sınırlama sebepleri, ancak ya da yalnız gibi sözcüklerle vurgulanmış ve tüketici bir biçimde belirlenmiş̧ir. Bunların yalnızca o maddede sayılan sebeplerle sinırlanabileceği öngörülmüssse, bunun dişındaki sebeplerle sınırlanamayacağ 1 açıktır ${ }^{122}$. AY'nin 22. maddesi de gezi özgürlüğünün "ancak" "ulusal güvenliği sağlama" ve "salgın hastalıkları önleme amaçlarıyla" sınırlanabileceğini düzenlemektedir ${ }^{123}$. Bu açıdan tam bir nitelikli yasa kaydı örneği olduğunu ve gezi hürriyetine getirilecek sınırlamanın; "yasayla" ve ancak "ulusal

\footnotetext{
1161985 KKTC AY md 11: 'Temel hak ve özgürlükler, özüne dokunmadan, kamu yararı, kamu düzeni, genel ahlak, sosyal adalet, ulusal güvenlik, genel sağlık ve kişilerin can ve mal güvenliğini sağlamak gibi nedenlerle ancak yasalarla kisitlanabilir'.

117 Fazıl Sağlam, Kuzey Kıbrıs Türk Cumhuriyeti Anayasa Hukuku Dersleri (1. Bası, Yakın Doğu Üniversitesi Yayınları, Lefkoşa 2015) $101 \mathrm{ff}$.

1181985 KKTC AY md 23/1: 'Herkes, vicdan, dini inanç ve kanaat özgürlüğüne sahiptir.'

1191985 KKTC AY md 21/2: 'Haberleşmenin gizliliği esastır. Yasanın gösterdiği durumlarda mahkeme veya yargıç tarafından yasaya uygun olarak verilmiş bir karar olmadıkça, bu gizliliğe dokunulamaz.'

120 Sağlam (n 117) $101 \mathrm{ff}$.

121 Necatigil (n 13) 44.

122 Sağlam (n 117) 105.

1231985 KKTC AY md 22.
} 
güvenlik" veya "salgın hastalıkları" önleme sebeplerine dayanması gerekir. Bu durumda AY'nin 11. maddesinde geçen genel sinırlama sebeplerine dayanmak söz konusu olmayacaktır. Bu husus hak ve özgürlüklerin sınırlanmasında, AİHM'in de gözettiği meşru sebebe bağl1lık ilkesini ortaya koymaktadır.

Fas1l 156 sayılı Yasa'da Bakanlar Kurulu'na bu yetkinin "kamu güvenliği”" ve "kamu düzeninin idamesi” amacıyla verildiği görülmektedir. Bu açıdan Yasa doğrudan gezi özgürlügünü sınırlandırdığ1 ve bu özgürlükte öngörülen özel sınırlama sebeplerine dayanmadığından anayasaya aykırı niteliktedir. Her ne kadar kamu düzeninin "kamu huzuru", "kamu güvenliği” ve "kamu sağlığı (genel sağlık)" kavramlarını da içerdiğ $1^{124}$ belirtilse de somut olayda Anayasa' daki açık düzenlemeler karşısında dolaylı bir ilişki kurulmasına yöneliktirler.

AYM'nin gezi özgürlüğüne ilişkin birkaç karar1 ${ }^{125}$ bulunmaktadır. Özgürlüğe ilişkin yaklaşımı bakımından önemli olanlarına kısaca değinmek gerekir. Yüksek Mahkeme'nin önüne gelen bir davada, yurt dışına çıkışına sınırlama getirilen bir kamu görevlisinin açtığı davadır. KKTC Yüksek İdare Mahkemesi olarak görev yapan Yüksek Mahkeme, gezi hürriyetine sınırlama getiren ilgili işlemin öncelikle yasallığı üzerinde durmuştur ${ }^{126}$. Mahkeme, Anayasa'ya göre gezi özgürlüğü ancak yasa ile sınırlanacağı belirtilmesine rağmen böyle bir yasa yapılmamış olduğuna işaret etmiştir. Bu durumda idari işlemlerle bu özgürlügün sınırlanamayacağına karar verilmiştir. Mahkeme bu özgürlügün "ancak özüne dokunmamak şartı ile yasa ile kısıtlanabileceğini" ve somut olaydaki idari işlemi yapan "Başbakanlığa böyle bir yetki ve görev veren herhangi bir yasal mevzuatın" bulunmadığını belirtmiştir ${ }^{127}$. Bu karar, idari işlemlerin gezi özgürlüğü gibi özgürlükleri sınırlayamayacağı konusunda yasallık ilkesine ilişkin olarak verdiği önemli bir karardır. Çalışmada dile getirilen anayasaya aykırılıklar açısından da son derece önemlidir.

AİHS'de sınırlamanın sınırı olarak "demokratik toplumda gereklilik" ilkesi geçmektedir. Demokratik toplumda gereklilik, KKTC AY'de yer alan hakkın özü kriterine göre daha belirgin, kullanılması daha kolay uluslararası sözleşmelerde de sınırlamanın sınırı olarak belirtilen bir güvencedir. $\mathrm{Bu}$ güvence ölçütü KKTC Anayasasında yer almasa dahi 39/1962 sayılı Onay Yasası ile iç hukuka geçirildiğinden, bu ilke bakımından bir boşluk olmadığını belirtmek gerekir ${ }^{128} \mathrm{AIIHM}$ bu kavramı, hakları sinırlamaya yönelik müdahalenin "zorlayıcı bir toplumsal ihtiyacı" karşılaması yani toplumun zorunlu bir ihtiyacına cevap vermesi ve "“izlenen

\footnotetext{
24 Gözler, Türk Anayasa Hukuku Dersleri (n 15) 230.

${ }_{125}$ KKTC AYM, KS 9/2009, D 4/2011, 20.10.2011.

126 KKTC'de Yüksek Mahkeme'nin yapısı için bkz KKTC AY md 144.

127 KKTC YIM, KS 103/98 (D 7/2003), 16.05.2003.

128 Necatigil (n 13) 47.
} 
meşru amaçla orantılı olması" biçiminde açıklamıştır. ${ }^{129}$ AİHM ölçütü ayrıca, sınırlandırmanın zorunlu olması, yapılacak son çare ya da alınabilecek son önlem olması şeklinde ifade etmektedir ${ }^{130}$. Demokratik toplumda gereklilik, ölçülülük ilkesiyle de ayrılmaz bir bütün içindedir. Ölçülülük ilkesi, seçilen müdahalenin amaca ulaşmak için elverişli, gerekli ve orantılı olması gerektiği şeklinde açıklanmıştır ${ }^{131}$. $\mathrm{Bu}$ hususlar olağan dönemde yapılan sınırlandırmanın sınırlarını ifade etmektedir. Fasıl 156'da BK'ya emirname çıkarma yetkisi verilmiş ancak yukarıda ifade edildiği gibi yasamanın yetkisinin çerçevesiz, sınırsız bir biçimde devri niteliğinde olup, AİHM'in ifade ettiği kaliteli bir yasa değildir.

Ayrıca KKTC AYM'nin başka bir kararında, Şans Oyunu Salonlarına KKTC yurttaşı olmayan veya ikametgâhı KKTC' de bulunmayan yurttaşlar dışında kimsenin giremeyeceğine ilişkin Yasa hükmünün gezi özgürlügüne (AY md 22) aykırı olup olmadığı tartışılmışıır. Yüksek Mahkeme "İkametgâhı bu ülkede bulunan yurttaşların Şans Oyunu Salonlarına girmesini yasaklayan bu düzenlemeyi yurttaşların gezi özgürlüğü ile ilişkilendirmeyi doğru" bulmadığını ifade etmiştir. Mahkeme "yurttaşların Şans Oyunu Salonu İzni olan tesislere girişleri dahi yasaklanmamıştır, yasaklanan bu tesislerde yer alan Şans Oyunu Salonlarına girmeleridir" şeklindeki gerekçesiyle Anayasa maddelerine aykırı olmadığına karar vermiştir ${ }^{132}$

Özgürlüklerin anayasal ilkelerle güvence altına alınmış ölçütlerine bakıldığında, (AY md 11 ve 12) getirilecek sınırlamaların "yasa ile öngörülme" ve "meşru bir sebebe" dayanması gerekir. Bir diğer ölçüt ise sınırlamanın özgürlüğün veya "hakkın özüne" dokunmamasıdır. Bir hak ve özgürlüğün amacına uygun biçimde kullanmasını zorlaştıran veya onu kullanılmaz hale getiren sınırlamalar hakkın özüne dokunmuş olur $^{133}$. Hakkın özü ilk olarak 1961 TC Anayasası'nda sınırlamaların güvence ölçütü olarak benimsenmiş, 1982 Anayasasında ise ancak 2001 değişiklikleri ile getirilmiştir ${ }^{134}$. KKTC Anayasa Mahkemesi kararlarında da hakkın özü bu şekilde açıklanmıştır ${ }^{135}$.

129 Zühtü Arslan, ‘Temel Hak ve Özgürlüklerin Sınırlandırılması: Anayasa'nın 13. Maddesi Üzerine Bazı Düşünceler' (2002) 19 Anayasa Yargısı 139, 150; Hasan Tahsin Fendoğlu, '2001 Anayasa Değişikliği Bağlamında Temel Hak ve Özgürlüklerin Sınırlanması' (2002) 18(1) Anayasa Yargısı 111, 137. Ayrıca TC AYM'si de demokratik toplumda gereklilik kavramını açıklarken yukarıdaki AİHM içtihadından yola çıkarak benzer tanımlamalarda bulunmuştur. Bekir Coşkun Başvurusu, AYM 2014/12151, 04.06.2015 para 51.

130 Betül Durmuş, 'Bireysel Başvuru Kararlarında Demokratik Toplumda Gereklilik Ölçütü' (2017) $2<$ https://anayasatakip. ku.edu.tr/wp-content/uploads/sites/34/2017/08/BetuCC881-DurmusCCA7-Bireysel-BasCCA7vuru-KararlarC4B1ndaDemokratik-Toplumda-Gereklilik-.pdf> Erişim Tarihi 27 Mart 2020.

131 Kemal Gözler, Insan Hakları Hukuku (2. Bası, Bursa: Ekin Yayınevi 2018) 370.

132 KKTC AYM, KS 9/2009, 2011.

133 KKTC AYM, KS 4/88, 4/88 (D 10/88), 27.10.1988.

134 Değişiklik öncesi TC AYM'si birçok kararında demokratik toplum düzenin gerekleri kavramını, hakkın özü kavramı ile tanımlamış ve/veya birlikte kullanmıştır. Gözler, Türk Anayasa Hukuku Dersleri (n 15) 242

135 KKTC AYM, KS 4/88, 1988. 
Hakkın özü ölçütünden daha belirgin, kullanılması kolay ve uluslararası sözleşmelerde (AİHS) benimsenen "demokratik toplumda gereklilik" ölçütü ise ${ }^{136}$ KKTC AY'de bulunmamaktadır. Ancak yine de KKTC iç hukukunda hak ve özgürlüklerin güvencesi olarak uygulanmalıdır. Zira 39/1962 sayılı Onay Yasası ile AİHS iç hukuka geçirildiğinden, bu güvence ölçütü bakımından da bir boşluk bulunmamaktadır ${ }^{137}$. AİHM bu kavramı, hakları sınırlamaya yönelik müdahalenin "zorlayıcı bir toplumsal ihtiyacı" karşılaması yani toplumun zorunlu bir ihtiyacına cevap vermesi ve “"izlenen meşru amaçla orantılı olması” biçiminde açıklamıştır ${ }^{138}$.

$\mathrm{Bu}$ güvence ölçütleri üzerinden Fasıl 156 incelendiğinde, yasama yetkisinin sınırsız bir biçimde devredildiği ve AİHM'in sıklıkla ifade ettiği kaliteli bir yasa olmadığı öncelikle belirtilmelidir. Yasallık ilkesi, özgürlüklere yapılacak müdahale bakımından yasanın çerçevesini aşmayacak şekilde yürütme organının düzenleyici ikincil işlemlerle düzenlemesine engel değildir. Temel esaslar ve genel çerçeve yasayla belirlendikten sonra, uzmanlık ve idare tekniğine ilişkin hususlarda yürütme organınca düzenleyici işlemler çıkarılabilir ${ }^{139}$. Sınırlamaların meşru bir sebebe bağll lık açısından dayanması ölçütüne göre Yasa'nın, gezi ve yerleşme özgürlüğünde (md 22) sayılan sebeplere dayanması gerekmektedir. Dolayısıyla idari işlem niteliğindeki emirnamelerin yetki, sebep, konu, maksat ve şekil-usul yönünden hukuka uygun olmas1 gerekir. Emirnameyle hak ve özgürlükler sınırlanabilmesi için, yürütmeye verilen bu yetkinin ifade edildiği Yasa yukarıda belirtilen ilkeleri içermelidir ${ }^{140}$.

Tüm bu değerlendirmelerden hareketle salgın hastalıkla mücadelede olağanüstü durum ve koşullar hâkim olmuş ve bunlar olağan hukuk kurallarıyla uzlaştırılmaya çalışılmıştır. Anayasal açıdan, olağanüstü bir dönemin koşulları altında olağan hukukun uygulanması, yukarıda görüldüğü gibi birçok açıdan ciddi sorunları beraberinde getirebilir. KKTC Cumhurbaşkanı bir açıklamasında, "korona virüs sürecinde, olağanüstü durum ilan edilmeden olağanüstü kararlar uygulandığını, ekonomi dışındaki alanlarda da kanun gücünde kararnameler çıkarıldığını" belirtmiştir. Cumhurbaşkanı "olağanüstü durum ilan edilmese de olağanüstü kararlar uygulandığının" altını çizerek, bu işlemlerin ileride hukuk sorunu haline gelmemesini temenni ettiğini belirtmiştir. Salgın hastalık sürecinde olağanüstü durum ilanı söz konusu olsaydı Cumhurbaşkanı Hükümet ve Meclis birlikte çalışabilirdi ${ }^{141}$.

136 Gözler, Insan Haklarl Hukuku (n 131) 394.

137 Necatigil (n 13) 47.

138 Arslan (n 129) 150; Fendoğlu (n 129) 137; Durmuş (n 130) 2.

139 TC AYM, BB No: 2012/1246,§ 60, Tahsin Erdoğan, 06.02.2014.

$140 \mathrm{Bu}$ açıdan KKTC AY md 12'nin de dikkate alınması gerekir 'Bu Anayasanın hiçbir kuralı, herhangi bir gerçek veya tüzel kişiye, zümre veya sınıfa, bu Anayasa ile güvence altına alınan Kuzey Kıbrıs Türk Cumhuriyeti’ni ve Kıbrıs Türk Halkının hak ve statüsünün değiştirilmesini veya bu Anayasanın kurduğu düzenin yok edilmesini veya tanınan temel hak ve özgürlüklerin ortadan kaldırılmasını amaçlayan hareketlere girişmek ve faaliyetlerde bulunmak hak ve yetkisini verir biçimde anlaşılamaz ve yorumlanamaz'.

${ }^{141}$ KKTC Cumhurbaşkanlığı B O, 'Kişilerden çok, kurumların demokratik, eşitlikçi ilişkileri önem taşır' (08.05.2020) $<$ https://kktcb.org/tr/cumhurbaskani-akinci-kisilerden-cok-kurumlarin-demokratik-esitlikci-iliskileri-onem-tasir-7592> Erişim Tarihi 08 Mayıs 2020. 
Cumhurbaşkanı değerlendirmeleri bu açıdan yerindedir, salgın hastalık sürecinde AY'ye uygun bir biçimde olağanüstü durumun ilanı yapılmış olsaydı, yukarıda ifade edilen birçok anayasal sorun ortaya çıkmayabilirdi. Böyle bir ilanın, iktidarın keyfiyetine ve takdir alanını genişleteceğine ve hak ve özgürlüklerin kullanılmasının durdurulması endişesiyle karşı çıkılmıştır. Ancak olağanüstü hâllerde dahi, yasaya uygun hareket edilmesi zorunluluğu, hukukun üstünlüğünün temel bir ilkesidir ${ }^{142}$. Yukarıda ifade edilenler, olağan hukukun olağanüstü duruma uygulanması sonucunda ortaya çıkan hukuki ve özelde de anayasal sorunlardır. Bu nokta, her ne kadar ayrı bir çalı̧̧manın konusu olsa da KKTC AY'sine göre olağanüstü durum ilanı halinde sokağa çıkma yasaklarının hukuki rejimi hakkında kısa bir değerlendirme yapılması uygun olacaktır.

\section{Sokağa Çıkma Yasağının Olağanüstü Hal Rejimi Çerçevesinde Değerlendirilmesi}

KKTC Anayasası'na göre “tabii afet, salgın hastalıklar ve ağır ekonomik bunalım hallerinde, Cumhurbaşkanı başkanlığında toplanan Bakanlar Kurulu, yurdun bir veya birden fazla bölgesinde veya bütününde, süresi üç ayı geçmemek üzere, olağanüstü durum" ilan edilebilirr ${ }^{143}$. Ayrıca olağanüstü durum ilanıyla, "ancak olağanüstü durumu oluşturan nedenlerin giderilmesi amacıyla" ve "sadece bu süre ile sınırlı kalınarak", (md 126/1) Anayasadaki bazı maddelerin kısmen veya tamamen durdurulması söz konusu olabilir (md 126) ${ }^{144}$. Anayasa'ya göre kısmen veya tamamen durdurulmas1 söz konusu olabilecek özgürlüklerden biri de somut olaya konu olan gezi ve yerleşme özgürlüğüdür. Anayasa'da olağanüstü durum ilanının sebeplerinden biri de "salgın hastalık" olduğundan düzenleme bu yönüyle makuldür.

Olağanüstü durum ilanı halinde temel hak ve özgürlüklerin sınırlanması rejiminde olağan kurallar (md 11) değil, AY'nin 126/2. maddesi uygulanır. Bu durumda da olağan hukuk çerçevesinde yukarıda ortaya koyduğumuz yasallık, meşru sebebe bağlılık, yasamanın yetki devri konusundaki anayasal sorunlar söz konusu olmayacak, gezi ve yerleşme özgürlüğüne hukuka uygun bir biçimde sınırlama getirilebilecekti.

Olağanüstü durumlar tamamıyla hukuksuz istisnai dönemler değildir. İçinde

142 AK Genel Sekreterliği, 'COVID-19 Sağlık Krizi Çerçevesinde Demokrasi, Hukukun Üstünlüğü ve İnsan Haklarına Saygı' (2020) <https://rm.coe.int/ak-genel-sekreteri-covid-19-uye-devletlere-yonelik-set> Erişim Tarihi: 30 Nisan 2020.

1431985 KKTC AY md 124.

1441985 KKTC AY md 126/1: ‘Anayasanın 124. ve 125. maddeleri uyarınca olağanüstü durum ilanına karar verilmesi halinde, bu karar Resmi Gazete'de yayımlanır ve derhal Cumhuriyet Meclisinin onayına sunulur. Cumhuriyet Meclisi tatilde ise derhal toplantıya çağrılır. Cumhuriyet Meclisi üye tamsayısının salt çoğunluğu ile, olağanüstü durum kararını veya süresini değiştirebilir; olağanüstü durumu kaldırabilir; Bakanlar Kurulunun istemi üzerine her defasında iki ayı geçmemek üzere süreyi uzatabilir'. Aynı maddenin 2. fikrası şu şekildedir; Herhangi bir olağanüstü durum ilânında, ancak olağanüstü durumu oluşturan nedenlerin giderilmesi ile sınırlı olarak sözü edilen olağanüstü durumun devamı süresince yürürlügüü kısmen veya tamamen durdurulan Anayasa maddeleri açıkça gösterilir. Ancak, bu gibi herhangi bir olağanüstü durum ilânında,, Anayasanın aşağıda öngörülen maddelerinin yürürlüğü durdurulabilir: 16. madde; 20. madde; 21. madde; 22. madde; 24. madde; 32. madde; 33. madde; 41. maddenin (5). fikrasının (ç) bendi; 42. madde; 48. madde; 49. maddenin (3). fikrasi; 53. madde ve 54. madde. 
bulunduğumuz salgın hastalıklar gibi kriz dönemlerinde hukuken tedbirlerin, "ancak olağanüstü durumu oluşturan nedenlerin giderilmesi amaciyla" ve "sadece bu süre ile sınırlı kalınarak" alınması anayasal bir zorunluluktur. Olağanüstü durumlarda hak ve özgürlüklerin durdurulması düzeyine varmayacak tedbirler de alınabilir. Durdurma halinde hak tamamen geçici olarak ortadan kalktığı için kullanılamayacaktır. Sınırlandırma halinde ise, o temel hak ve özgürlük tamamen ortadan kalkmamış sınırlandırılmıştır, dolayısıyla bazı kullanım alanları hala daha vardır ${ }^{145}$.

Olağanüstü durumda alınacak tedbirler, Cumhurbaşkanının başkanlığında toplanan Bakanlar Kurulu tarafından alınır ve "Olağanüstü durum ve sıkıyönetim süresince, Bakanlar Kurulu, olağanüstü durumun veya sıkıönetimin gerekli kıldığg konularda, yasa gücünde kararname çıkarabilir" "146. Olağanüstü durum ilanı ile olağanüstü durumlarda çıkarılacak kararnameler, "olağanüstü durumun gerekli kıldığı konularda" çıkarılmalıdır. Bu kararnameler ile olağanüstü durum gereği 126. maddeye uygun olmak şartıyla, mali yükümlülükler getirilebilir veya olağan dönemin sınırlama rejimi dışında kişisel ve siyasal hak ve özgürlükler kısıtlanabilir. Ancak olağanüstü durum kararnameleri RG'de yayımlanarak, olağanüstü durum ilanında olduğu gibi (md 126/1) Meclis'in onayına sunulur. Meclis, üye tamsayısının salt çoğunluğu ile kararnameleri reddedebilir veya onaylayabilir. Meclis bu yetkisini 90 gün içerisinde kullanmak zorundadır ${ }^{147}$.

Olağanüstü durum ilanına ilişkin kamuoyunda ortaya çıkan endişeler genellikle idareye güvensizlikten kaynaklanır. Korona virüs salgın hastalığı sürecinde birçok demokratik ülkede olağanüstü hâl ilanı söz konusu olmuş, AİHS askıya alınmıştır. Zira olağan hukuk düzeninde bu tür olağanüstü dönemlerle başa çıkabilecek hukuk kuralları genellikle bulunmamakta veya olağan hukuk yetersiz kalmaktadır. Avrupa Konseyince salgın hastalıkla başa çıkmak üzere alınacak her yeni kuralın, anayasaya ve uluslararası standartlara uygun olmas1 gerektiği ve devletlerin bu kapsamda olağanüstü ilanı öngörmelerinin mümkün olduğunu belirtmiş̧ir. Ayrıca böyle bir yetki bakımından, "muhtemel suiistimalinin önlenmesi için parlamento tarafından yürütmeye sınırlı bir yetki" verilmelidir. Bu istisnai süreç ve beraberindeki tedbirlerin "süreyle sinırlı olması" ve krizi "en kısa sürede atlatmak amacinda" olması ve "hukukun üstünlügü̈” ile "demokratik ilkelere saygının” zedelenmemesi gerekir ${ }^{148}$.

\footnotetext{
145 Gözler, Türk Anayasa Hukuku Dersleri (n 15) 253.

1461985 KKTC AY md 128/1: 'Olağanüstü durum ve sıkıyönetim süresince, Cumhurbaşkanının başkanlığında toplanan Bakanlar Kurulu, olağanüstü durumun veya sıkıyönetimin gerekli kıldığı konularda, yasa gücünde kararname çıkarabilir. $\mathrm{Bu}$ kararnameler, Resmi Gazete'de yayımlanır ve derhal Cumhuriyet Meclisinin onayına sunulur. Bu kararnameler, Cumhuriyet Meclisinin üye tamsayısının salt çoğunluğunun oyu ile reddedilmedikçe, olağanüstü durum ve sıkıyönetim süresince yürürlükte kalır'.

1471985 KKTC AY md 128 ve 112.

148 ‘COVID-19 Sağlık Krizi Çerçevesinde Demokrasi, Hukukun Üstünlüğü ve İnsan Haklarına Saygı’ (n 142) (2020) Erişim Tarihi: 30 Nisan 2020.
} 
Süreç alınması gerek tedbirlerin olağanüstü olmasını doğal olarak zorunlu kılmaktadır. KKTC'de sokağa çıkma yasağını öngören emirnameler ile bu yasağa uymayanlar bakımından yasa gücünde kararnamelerle yaptırım öngörülmüştür. Kararnamelerle öngörülen yaptırım ise en temel hukuk ilkelerinden biri olan "suç ve cezada kanunilik" ilkesi bakımından yukarıda da görüldüğü üzere tartışılmıştır.

\section{Sonuç}

Anayasa'ya göre hukukun üstünlüğüne dayanan bir devlet olarak KKTC'de gezi ve yerleşme özgürlüğüne aykırı bir biçimde getirilen sınırlamalar, yasayla değil adsız düzenleyici işlem olan "emirnameler" ile getirilmiştir. İçinde bulunulan durumun zorunluluklar ve tedbirleri beraberinde getirdiği düşünülebilir. Ancak çalışmada ele alınan konuda bir değil birçok hukuki sorun olduğu görülmektedir. Haklara ve özgürlüklere getirilen sınırlamalar yasallık ilkesini ihlal etmesi dışında, meşruiyetini yitirmiş yasalarla kriz yönetimi yapılmıştır. Bundan en az hükümet kadar parlamento da sorumludur. Zira KKTC Cumhuriyet Meclisi 2018 tarihli güncel bir Bulaşıcı Hastalıklar Yasası kabul etmiş, epidemi, Dünya Sağlık Örgütü gibi çağdaş kamu sağlığı ilkeleri içeren bu düzenlemede, AY'de açıkça belirtilmesine rağmen gezi ve yerleşme özgürlüğünün salgın hastalıklar halinde sınırlanabilmesi konusunda, yürütmeye yetki verilmemiştir. Hukukun üstün olduğu KKTC'de sokağa çıkma yasakları İngiliz döneminin 4 maddelik bir Yasasına dayandırılmış, hatta esasları emirname ile ortaya konulmuştur. KKTC yönetim sistemine ve hukukuna son derece yayılmaya başlamış olan emirname rejiminin hukuk devleti ilkesinden sapmayı beraberinde getirdiğini belirtmek gerekir.

Avrupa Konseyi, korona virüsle ilgili müdahalelerin meşru olduğunu, ancak bunun demokrasi, insan hakları ve hukuk devletine aykırı bir biçimde yapılmaması gerektiğine vurgu yapıyor ${ }^{149}$. Avrupa Konseyi salgın hastalıkla mücadelede, üye devletlerin olağanüstü hallerde, şartlara bağlı olarak, AİHS'de yer alan bazı yükümlülükleri, iç hukukta temeli olması ve demokratik toplumda gerekli olması koşullarıyla askıya alabileceklerini olağan karşılamaktadır ${ }^{150}$. Ancak devletler insan hakları standartlarına uygun davranmalıdırlar. Olağanüstü istisnai dönemler, devletin normal hukuk düzeninin kuralları ile karşılanmasına imkân olmayan tehlike veya tehditlerin söz konusu olduğu dönemlerdir. Yeni korona virüs salgın hastalığı da şüphesiz bu tür bir tehdit içermektedir. İdarenin bu tür dönemlerde, mahiyeti gereği takdir yetkilerini genişletmesi ve temel hak ve özgürlüklere olağan zamanlara oranla daha ileri ölçüde sınırlamalar getirmesi söz konusudur ${ }^{151}$. Burada çelişki yaratan

\footnotetext{
149 Deutsche Welle, 'Koronavirüs İnsan Haklarına da Bulaşıyor' $(2020)<$ https://www.dw.com/tr/koronavirC3BCs-insanhaklarC4B1na-da-bulaC59FC4B1yor/a-53127730 > Erişim Tarihi: 17 Nisan 2020.

150 'COVID-19 Sağlık Krizi Çerçevesinde Demokrasi, Hukukun Üstünlüğü ve İnsan Haklarına Saygı' (n 142) Erişim Tarihi: 30 Nisan 2020.

151 Özbudun Ergun, Türk Anayasa Hukuku (17. Bası, Ankara: Yetkin Yayınları 2017) 333.
} 
durum olağanüstü dönem içerisinde olağan hukuk kurallarının örtüşmemesidir. Süreç, tehdit ve hatta alınan tedbirler olağanüstü ancak hukuk olağandır. Dolayısıyla olağanüstü tedbirlerin olağan hukukla uzlaştırılması önemli aykırılıkları beraberinde getirmektedir.

Hakem Değerlendirmesi: Dış bağımsız.

Çıkar Çatışması: Yazarlar çıkar çatışması bildirmemiştir.

Finansal Destek: Yazarlar bu çalışma için finansal destek almadığını beyan etmiştir.

Yazar Katkısı: Çalışma Konsepti/Tasarımı: D.Ç.U., E.U.; Veri Toplama: E.U., D.Ç.U.; Veri Analizi /Yorumlama: D.Ç.U., E.U.; Yazı Taslağı: E.U., D.Ç.U.; İçeriğin Eleştirel İncelemesi: D.Ç.U.; Son Onay ve Sorumluluk: D.Ç.U., E.U.

Peer-review: Externally peer-reviewed.

Conflict of Interest: The authors have no conflict of interest to declare.

Grant Support: The authors declared that this study has received no financial support.

Authors Contributions: Conception/Design of study: D.Ç.U., E.U.; Data Acquisition: E.U., D.Ç.U.; Data Analysis/ Interpretation: D.Ç.U., E.U.; Drafting Manuscript: E.U., D.Ç.U.; Critical Revision of Manuscript: D.Ç.U.; Final Approval and Accountability: D.Ç.U., E.U. 


\section{Bibliyografya/Bibliography}

27/2013 Say1l İyi İdare Yasas1, Kanun Numaras1: 27/2013, Kabul Tarihi:11.11.2013. <https:// www.mahkemeler.net/birlestirilmis/27-2013.doc> Erişim Tarihi 10 Ocak 2020.

39/1962 Sayılı İnsan Haklarını ve Ana Hürriyetleri Korumaya Dair Avrupa Sözleşmesi Ve Buna Ek Protokolün Tasdiki Hakkında Yasa, Kanun Numaras1: 39/1962, Kabul Tarihi:24.05.1962, Cyprus Government Gazette No 157, Supplement I. <https://www.mahkemeler.net/ birlestirilmis/39-1962.doc> Erişim Tarihi: 16 Nisan 2020.

45/2018 Sayılı Bulaşıcı Hastalıklar Yasası, Kanun Numarası:45/2018, Kabul Tarihi: 10.12. 2018 $<$ https://www.mahkemeler.net/birlestirilmis/45-2018.docx> Erişim Tarihi 17 Mart 2020.

Akkanat S, 'Kurucu İktidara Dayalı Bir Demokrasinin İmkânı: Siyasal Bir Yaklaşımı'(2015) 48( 2) Amme İdaresi Dergisi 1-21.

Ali Karatay Başvurusu, AYM 2012/990, 10.12.2014.

Altıparmak K ve Karahanoğulları O, 'Pyrrhus Zaferi: Leyla Şahin/Türkiye, AİHM/Hukuk, Düzenleyici İşlem/Kanun' (2004) 3(1) Hukuk ve Adalet Dergis 249-276.

Arıkan C, Türk Anayasa Hukukunda Yasama Yetkisinin Devredilmezliği İlkesi ( Doktora Tezi, Ankara: Ankara Üniversitesi 2011).

Arslan Z, 'Temel Hak ve Özgürlüklerin Sınırlandırılması: Anayasa'nın 13. Maddesi Üzerine Bazı Düşünceler' (2002) 19 Anayasa Yarg1s1 139-155.

Association Ekin v. Fransa App no 39288/98 (ECHR, 2001) < https://hudoc.echr.coe.int/ eng\#\{itemid:[001-59603]\}> Erişim Tarihi 19 Nisan 2020.

Atay Ender E, 'Hukukta Meşruiyet Kavramı' (1997) 1(2) Gazi Üniversitesi Hukuk Fakültesi Dergisi 121-166.

AK Genel Sekreterliği, ‘COVID-19 Sağl1k Krizi Çerçevesinde Demokrasi, Hukukun Üstünlüğü ve İnsan Haklarına Saygı' (2020) < https://rm.coe.int/ak-genel-sekreteri-covid-19-uye-devletlereyonelik-set> Erişim Tarihi 30 Nisan 2020.

Azer C, 'KKTC'de Düzenleyici İşlemlerin Denetlenme(me)si Sorunu Ve Buna Çözüm Yolu: İyi İdare Yasası' (2018) 32(142) Türkiye Barolar Birliği Dergisi 429-452<http://tbbdergisi. barobirlik.org.tr/m2019-142-1854> Erişim Tarihi 21 Mart 2020.

Bekir Coşkun Başvurusu, AYM 2014/12151, 04.06.2015.

Bjørnskov C ve Voigt S, The State of Emergency Virus, 'Verfassungsblog On Matters Constitutional' (2020)<https://verfassungsblog.de/the-state-of-emergency-virus/> Erişim Tarihi 05 Nisan 2020.

Curfew Law 1955, "A Law to Provide for The Imposition of Curfews in the Interests of Public Safety and the maintenance of Public Order" Supplement No. 2, Legislation The Statute Laws of Cyprus No. 11 of 1955 The Cyprus Gazette No. 3821, Kabul Tarihi: 05.05.1955 <http://www. cylaw.org/nomoi/arith/1955_1_017.pdf> Erişim Tarihi 02 Nisan 2020.

Çelik Ulusoy D, 'Kıbrıs'ta Anayasa Yargısı ve Bireysel Başvuru' (2017) < doi:https:// anayasatakip.ku.edu.tr/wp-content/uploads/sites/34/2017/10/Demet-CCCA7elik-UlusoyKC4B1brC4B1sE28099ta-Anayasa-YargC4B1sC4B1-ve-Bireysel-BasCCA7vuru1.pdf> Erişim Tarihi 19 Nisan 2020.

Çelik Ulusoy D, 'Kuzey Kıbrıs Türk Cumhuriyeti’nde Cumhurbaşkanlığı Seçimlerinin Ertelenmesi ve Cumhurbaşkanının Göreve Devamına İlişkin Parlamento Kararının Yarattığı Anayasal Sorunlar’ (2020) 22(2) Dokuz Eylül Üniversitesi Hukuk Fakültesi Dergisi, Yayınlanmas1 Bekleniyor. 
Deutsche W, 'Koronavirüs İnsan Haklarına da Bulaşıyor' (2020) <https://www.dw.com/tr/ koronavirC3BCs-insan-haklarC4B1na-da-bulaC59FC4B1yor/a-53127730> Erişim Tarihi 17 Nisan 2020.

Durmuş B, 'Bireysel Başvuru Kararlarında Demokratik Toplumda Gereklilik Ölçütü' (2017) <https:// anayasatakip.ku.edu.tr/wp-content/uploads/sites/34/2017/08/BetuCC881-DurmusCCA7-BireyselBasCCA7vuru-KararlarC4B1nda-Demokratik-Toplumda-Gereklilik-.pdf $>$ Erişim Tarihi: 27 Mart 2020.

Eren A, 'Anayasa Mahkemesinin Kanun Hükmünde Kararnamelere İlişkin İçtihadı Doğrultusunda Cumhurbaşkanlığı Kararnamelerinin Değerlendirilmesi' (2019) 36( 1) Anayasa Yargısı 1-72.

Tufan Erhürman, Yüksek İdare Mahkemesi'nin Görev Alanı, (1. Bası, Işık Kitabevi, Lefkoşa, 2013).

Tufan Erhürman, Kuzey Kıbrıs Türk Cumhuriyeti İdari Yargılama Hukuku, (1. Bası, Işık Kitabevi, Lefkoşa, 2012).

Eşitli Aygün E, 'Suçların ve Cezaların Kanuniliği İlkesi' (2013) 104 TBB Dergisi 226-246<http:// tbbdergisi.barobirlik.org.tr/m2013-104-1249> Erişim Tarihi 19 Nisan 2020.

Fasıl 156 Sokağa Çıkma Yasağı Yasas1, Kanun Numaras1: 1955, Kabul Tarihi: 2.05.1955, Suplement No 2 The Cyprus Gazette No 3821 05.05.1955 <https://www.mahkemeler.net/ birlestirilmis/f_156.doc> Erişim Tarihi 27 Mart 2020.

Fasıl 260 Karantina Yasası (1932), Karantinaya Koymayı Düzenleyen ve Tehlikeli Enfeksiyöz Hastalıkların Ülkeye Girişini Ve Yayılmasını Veya Ülkeden Başka Yerlere Geçmesini Önleyici Ek Kurallar Öngören Yasa.

Fendoğlu H T, '2001 Anayasa Değişikliği Bağlamında Temel Hak ve Özgürlüklerin Sınırlanması' 200218 (1) Anayasa Yarg1s1 111-149.

Gazette The Cyprus, Supplement No. 3, Subsidiary Legislation (28.11.1957) <https:// sbaadministration.org/home/legislation/01_02_09_02_PartII-SubLeg-Cyprus/CyGaz-.pdf $>$ Erişim Tarihi 10 Nisan 2020.

Görür H, 'Hukuk Devletinde Meşruiyet Sorunu' Hukuk Politik (2010)<https://www.hukukpolitik. com.tr/2016/12/05/hukuk-devletinde-mesruiyet-sorunu> Erişim Tarihi 02 Nisan 2020.

Gözler K, Anayasa Hukukunun Genel Esasları (10. Bası, Bursa: Ekin Yay 2018).

Gözler K, Anayasa Hukukunun Genel Teorisi: Cilt 1 (2. Bas1, Bursa: Ekin Yay 2020).

Gözler K, Insan Hakları Hukuku (2. Bası, Bursa: Ekin Yay 2018).

Gözler K, Türk Anayasa Hukuku Dersleri (22. Bas1, Bursa: Ekin Yay 2018).

Gül C, İktidarın Sinırlandırılması ve Hukuk Devleti (1. Bas1, Ankara: Adalet Yayınevi 2010).

Gülcü v Türkiye App. No. 17526/10 (ECHR, 2016).

Greece v. United Kingdom, App. No. 176/56, (26.09.1958).

Jefferson T, 'Thomas Jefferson to James Madison'(1789) 15(27) Princeton University Press 1958 392$8<$ https://jeffersonpapers.princeton.edu/selected-documents/thomas-jefferson-james-madison> Erişim Tarihi 20 Mart 2020.

Kalabalık H, 'İdare Hukukunda Takdir Yetkisi Kavramı Ve Benzer Kurumlarla Karşılaştırılması' (1997) 1(2) Gazi Üniversitesi Hukuk Fakültesi Dergisi 205-232.

Kaneti S, ‘Anayasa Mahkemesi Kararları'na Göre Yasama Yetkisi İle Yürütmenin Düzenleme Yetkisinin Sinırları' (1994) 54(1-4) İstanbul Üniversitesi Hukuk Fakültesi Mecmuası 33-44.

Karantina Yasas1, The Quarantine Law, 1932, Kabul Tarihi: 26.02.1932. RG 09.03.19327 Cyprus Gazette No. 2201 of the No. 17 of 1932 < http://www.cylaw.org/nomoi/arith/1932_1_017.pdf> Erişim Tarihi 03 Nisan 2020. 
Kıbrıs Cumhuriyeti Anayasası, Numarası: 0/1960, Kabul Tarihi:06.04.1960 Yürürlük Tarihi:16 Ağustos $1960<$ https://www.mahkemeler.net/cgi-bin/anayasa/1960.doc> Erişim Tarihi 22 Nisan 2020.

KKTC Anayasa Mahkemesi, S 7/89 (D6/89), 30.06.1989 <https://www.mahkemeler.net/cgi-bin/ yenikararara3.aspx> Erişim Tarihi 22 Mart 2020.

1985 KKTC Anayasas1, Kabul Tarihi: 5.05.1985. RG 07.05.1985. <https://www.mahkemeler.net/ cgi-bin/anayasa/anayasa.doc> Erişim Tarihi 02 Ekim 2019.

KKTC AYM, KS 21/2009, (D 3/2011), 2011.

KKTC AYM, KS (D 3/2012), Birleştirilmiş 12-13-14-15-16/2012 (D 3/2012), 2012.

KKTC AYM, KS 14/2015, D 9/2017, 29.06.2017.

KKTC AYM, KS 23/85 (D 8/87), 04.06.1987.

KKTC AYM, KS 4/2006, (D 1/2007), 2007.

KKTC AYM, KS 4/88, 4/88 (D 10/88), 27.10.1988.

KKTC AYM, KS 7/89 (D 6/89), 30.06.1989.

KKTC AYM, KS 9/2009, D 4/2011,20.10.2011.

KKTC AYM, KS 9/93 (D 5/95), 29.06.1995.

KKTC AYM, KS AM 5/97, AM 5/97 (D 1/98), 1998.

KKTC AYM, KS D 2/2012, D 2/2012, Birleştirilmiş Anayasa Mahkemesi: 20 ve 21/2012, 16.08.2012.

KKTC AYM, KS D 3/2016- 15/2015, 07.04. 2016.

KKTC Başbakanlık, 'Bakanlar Kurulu Kararları Açıklandı' (13.03.2020) <http://kktcbasbakanlik. org/ArtMID/3765/ArticleID/124068/> Erişim Tarihi 13 Mart 2020.

KKTC Cumhurbaşkanlığı B O, 'Kişilerden çok, kurumların demokratik, eşitlikçi ilişkileri önem taşır' (08.05.2020) <https://kktcb.org/tr/cumhurbaskani-akinci-kisilerden-cok-kurumlarindemokratik-esitlikci-iliskileri-onem-tasir-7592> Erişim Tarihi 08 Mayıs 2020.

KKTC Resmi Gazete 22.03.2020/S 48, Kısmi Sokağa Çıkma Yasağı Emirnamesi (22.03.2020) (KKTC Bakanlar Kurulu, Düzenleyen, \& A. S.-K. EK III, Prodüktör), <https://basimevi.gov. ct.tr/> Erişim Tarihi 25 Mart 2020.

KKTC Resmi Gazete 25.03.2020/S 50, KKTC Başbakanlık Basımevi (25.03.2020) <https:// basimevi.gov.ct.tr/> Erişim Tarihi 25 Mart 2020.

KKTC YIM, KS 103/98 (D 7/2003), 16.05.2003.

KKTC YIM, KS 81/2007, D 4/2009, 27.02. 2009.

Kıbrıs Türk Federe Devleti Anayasası (KTFD), Numaras1:0/1975, Numaras1: 0/1975, Kabul Tarihi: 13.02.1975 Yürürlük Tarihi: 08.06.1975<https://www.mahkemeler.net/cgi-bin/anayasa/ ktfdana.doc > Erişim Tarihi 10 Nisan 2020.

KTFD AYM, KS 18/78, 27.04.1979.

KTFD AYM, KS D 1/82, D 1/82, Yargitay/Asli Yetki İstinaf 1/82, 01.06.1982.

Minister of Health Cyprus, Decree on Quarantine (Determination of Measures to Prevent Spread of the COVID-19 Coronavirus) Decree (No 18) of 2020, <https://www.pio.gov.cy/coronavirus/en/ press/.pdf> Erişim Tarihi 18 Nisan 2020.

Necatigil Z, Kuzey Kıbrıs Türk Cumhuriyeti’nde Anayasa ve Yönetim Hukukunun Esasları (2. Bası, Lefkoşa: Işı1k Kitabevi 2015).

Onur Karahanoğulları, 'İngiliz Hukukunda İkincil Yasama' (1995), AÜSBF, 03(50), 212-230. $<$ https://dergipark.org.tr/en/download/article-file/36423> Erişim Tarihi 16 Mart 2020. 
Özay İ, Günışı̆̆ında Yönetim (1. Bası, İstanbul: Alfa Yay 1994).

Özbudun E, ‘İngiliz Hukukunda Hükümet Tasarrufları’ (1961) 18(1) Ankara Üniversitesi Hukuk Fakültesi Dergisi 333-372.

Özbudun E, Türk Anayasa Hukuku (17. Bas1, Ankara: Yetkin Yayınları 2017).

Özpolat H, 'Anayasa Mahkemesi'nin Bireysel Başvuru Kararlarında Maddi Anlamda Kanun Kriteri' (2018) 9(33) TAAD 609-622.

Sağlam F, Anayasa Hukuku Ders Notları, (1. Bası, Lefkoşa: Yakın Doğu Üniversitesi Yayınları 2013).

Sağlam F, Kuzey Kıbrıs Türk Cumhuriyeti Anayasa Hukuku Dersleri (1. Bası, Lefkoşa: Yakın Doğu Üniversitesi Yayınlar1 2015).

Gözübüyük Ş, Yönetim Hukuku (13. Bas1, Ankara, Turhan Kitabevi 2000).

Van Der Sloot B, 'Is All Fair in Love and War? An Analysis of the Case Law on Article 15 ECHR' (2014) 53 (1) Military Law and the Law of War Review < https://bartvandersloot.com/ onewebmedia/Is_all_fair_in_love_and_war_forthcomming.pdf $>26.04 .2020$.

Strauss David A, 'Common Law, Common Gorund and Jefferson's Principle' (2003) 112 The Yale Law Journal 1717-1755.

Sunday Times v Birleşik Krallık (no 1) Series A no 30, App No 6538/74 (ECHR, 26.04.1979).

TC AYM, BB No: 2012/1246,§ 60, Tahsin Erdoğan, 06.02.2014.

TC AYM, E 1967/41, K 1969/57, 25.10.1969.

TC AYM, E 1993/5,K 1993/25, 06.07.1993.

Teziç E, 'Yasama Yetkisi ve Kanun Hükmünde Kararnameler' (1972) 5(3) Amme İdaresi Dergisi 3-14.

The Quarantine Law, 1932, Kabul Tarihi: 26.02.1932. RG 09.03.19327 Cyprus Gazette No. 2201 of the No. 17 of 1932 < http://www.cylaw.org/nomoi/arith/1932_1_017.pdf> Erişim Tarihi 03 Nisan 2020.

Yeliz Şanlı Atay, 'Türk İdare Hukukunda Adsız Düzenleyici İşlemler' (2011) (Yayımlanmamış Doktora Tezi T.C. Ankara Üniversitesi Sosyal Bilimler Enstitüsü Kamu Hukuku (İdare Hukuku) Anabilim Dalı, Tez Danışmanı: Prof. Dr. Metin Günday, Ankara) 23-28. <https://dspace.ankara. edu.tr/xmlui/bitstream/handle/20.500.12575/33957/Sanli\%20Atay_Yeliz_tez.pdf?sequence=1> Erişim Tarihi 15.02.2021.

Yılmaz H, ’Türk Hukukunda Düzenleme Yetkisinin Tarihsel Gelişimi ve Niteliği' (2014) 110 Türkiye Barolar Birliği 220-240 <http://tbbdergisi.barobirlik.org.tr/ViewPDF- i-1345> Erişim Tarihi 10 Nisan 2020. 